\title{
A 1.3 million year record of synchronous faulting in the hangingwall and border fault of a half-graben in the Malawi (Nyasa) Rift
}

Tannis McCartney*1, Christopher A. Scholz ${ }^{1}$

${ }^{1}$ Department of Earth Sciences, Syracuse University, Syracuse, NY 13244, USA

Corresponding author:

Tannis McCartney

Department of Earth Sciences

204 Heroy Geology Laboratory

Syracuse, NY 13244 USA

$1-315-744-7644$

tmccartn@ syr.edu

Co-author:

Christopher A. Scholz

Department of Earth Sciences

204 Heroy Geology Laboratory

Syracuse, NY 13244 USA

cascholz@syr.edu

Keywords:

Malawi (Nyasa) Rift; East African Rift System; syndepositional faulting; border fault migration; half-graben. 


\begin{abstract}
This paper analyzes throw-depth (T-z) profiles from a high resolution $2 \mathrm{D}$ reflection seismic grid in the central basin of Lake Malawi to investigate whether evidence exists: 1) for migration of faulting away from the border fault of the half-graben; and 2) that faults in the hangingwall lengthened over the last 1.3 million years. We use the high-precision age model from a 2005 scientific drilling project in our study area to constrain the ages of our seismic horizons and examine a fault array and two individual faults within the hangingwall of the central basin border fault. We account for climatic and sedimentological controls on stratal growth with a lake-level curve that accompanies the age model. A comparison of our hangingwall T-z profiles with published throw-distance (T-x) profiles for the border fault shows synchronous faulting over the last 1.3 m.y. rather than basinward migration of faulting. Furthermore, we find no evidence for significant propagation of the tips of the hangingwall faults in the last $1.3 \mathrm{~m} . \mathrm{y}$. and conclude that the lack of basinward migration of faulting is a consequence of strain localization on faults established at an early stage in basin development.
\end{abstract}




\section{Introduction}

It is well established that continental rift basins are bounded by border faults, forming either grabens or half-grabens, but the role faults in the hangingwalls of these border faults play in extensional processes remains enigmatic. In the East African Rift System (EARS), the rift basins are predominantly half-graben basins (Rosendahl, 1987; Faulds and Varga, 1998; e.g.

Chorowicz, 2005). In cross-section (Fig. 1), a half-graben basin consists of a border fault margin with a steep fault that can accommodate thousands of meters of slip, a flexural margin opposite the border fault, and sediment fill that thickens toward the border fault (e.g. Scholz and Contreras, 1998; Withjack et al., 2002). In this study, we define a hangingwall fault as a fault within the hangingwall block of the border fault (Fig. 1). We describe two types of secondary fault geometries in the hangingwall: fault arrays and intrabasin faults. We observe stratal growth in the hangingwall of a fault array and two intrabasin faults within the hangingwall of the central basin's main border fault system throughout the last 1.3 million years, synchronous with fault activity interpreted on the border fault.

Basinward migration of fault activity, away from the border fault, has been documented in the Main Ethiopian Rift (Ebinger, 2005; e.g Corti, 2009) and the Aegean Sea (e.g. Dart et al., 1995; Goldsworthy and Jackson, 2001), however it is rarely preserved in ancient continental rifts (Dart et al., 1995). Goldsworthy and Jackson (2001) identify four possible causes of border fault migration: 1) There is a maximum stress that fault-controlled topography can maintain. When it is reached, new faults develop at a distance prescribed by the maximum stress. This hypothesis fits with the idea that pre-rift fabric controls strain localization in rift basins (Walsh et al., 2002; Paton, 2006). 2) Sediment loading in the hangingwall combined with footwall erosion reduces the density and topographic contrasts that influence stress fields. Pre-existing stress conditions 
must be known to evaluate this hypothesis (Goldsworthy and Jackson, 2001). 3) Lower crustal flow smoothes out lateral variations in crustal thickness, but only if the crust is sufficiently heated and weakened to allow flow (Goldsworthy and Jackson, 2001). 4) Fault patterns adjust for a rotation about a vertical axis. This mechanism does not explain migration between sub-parallel fault systems (Goldsworthy and Jackson, 2001).

Modeling results suggest that continental rifts undergo two main stages of faulting, the Boundary Faults Stage and the Internal Faults Stage (Corti, 2008; Agostini et al., 2009; Corti et al., 2010, 2013). The timing of the transition between the two stages is dependent upon several boundary conditions, where the most important are sediment supply and pre-rift lithospheric structure. According to modeling results, the transition is slow if the crust is thick and syn-rift sedimentation is sufficient (Corti et al., 2010).

The central basin of Lake Malawi is one of the most structurally complex parts of the Malawi Rift, which is at the southern end of the western branch of the EARS (Fig. 2a). The hangingwall of the central basin border fault, on the west side of Lake Malawi, contains complex fault arrays and individual faults, with many oriented oblique to the border fault system (Fig. 2c, Fig. 3).

The Western Branch of the Malawi Rift is an important place to study early syn-rift basin development because it is a geologically-young continental rift. Post-rift deformation has not yet removed early syn-rift sediments or overprinted syn-rift deformation and salt tectonics are not a factor here. Chronological studies in sedimentary basins are needed to address uncertainties in the timing of rift progression (Roberts et al., 2012). Because this branch is largely amagmatic, the sedimentary basins in the long-lived lakes have complete records of continental rifting. Consequently, the Lake Malawi datasets provide a unique opportunity to put high-resolution 
time constraints on the evolution of an $\sim 8000 \mathrm{~km}^{2}$ rift basin. These time constraints have broader implications for studying rift segments. The observation that hangingwall faulting and border faulting are synchronous implies that border faults did not migrate. Therefore, the oldest syn-rift sediments have not been recycled by border-fault migration (c.f. Dart et al., 1995).

Here, we integrate three vintages of $2 \mathrm{D}$ reflection seismic data with an age model for the last 1.3 million years of sedimentation in the central basin of Lake Malawi (Lyons et al., 2015) to examine syntectonic deposition in the upper crust of the central basin of Lake Malawi. The sedimentary record, as observed in time-migrated reflection seismic profiles, can be used to quantify fault growth. In particular, we use stratal growth, a change in stratal thickness between the hangingwall and footwall of a fault, to understand fault evolution. The age model is from a 2005 scientific drilling program (Scholz et al., 2011a) that collected over $600 \mathrm{~m}$ of core at two sites in Lake Malawi, including $380 \mathrm{~m}$ at hole 1B in the central basin drillsite.

\section{Geological Setting}

\subsection{Malawi Rift}

The Malawi Rift is just over $700 \mathrm{~km}$ long (Specht and Rosendahl, 1989) and is located near the south end of the $\sim 4000 \mathrm{~km}$ long EARS (Fig. 2). Following the onset of the Afar Plume Episode $30 \mathrm{Ma}$ (Burke and Gunnell, 2008), rifting progressed southward along the length of the EARS (Chorowicz, 2005) in two principal branches: the Eastern/Kenya Branch and the Western Branch (Ebinger et al., 1989). These branches follow Proterozoic mobile belts (Nyblade and Brazier, 2002; Corti et al., 2007; Morley, 2010). The lacustrine basins of the Western Branch are largely amagmatic and deformation is primarily accommodated by seismicity (Morley et al., 1990). Estimates for the onset of rifting in the Western Branch are commonly cited as $\sim 9-12 \mathrm{Ma}$ 
(Ebinger et al., 1989; Cohen et al., 1993; Tiercelin and Lezzar, 2002), but recent absolute age dating from the Rukwa Rift suggest 25 Ma (Roberts et al., 2012).

In the Malawi Rift, focal mechanisms of earthquakes that occurred between 1976-2011 indicate extension occurred in west-east and northwest-southeast directions (Fagereng, 2013). Normal faulting is currently the dominant kinematic behavior although strike-slip faults do occur in the region (Delvaux and Barth, 2010). This behavior is consistent with recent modeling of presentday kinematics, which suggests the southern part of the Somalia plate is moving approximately eastward (Saria et al., 2014). The north basin is interpreted as a pull-apart basin associated with a dextral strike-slip zone that connects it to the Rukwa and southern Tanganyika fault zones (Wheeler and Karson, 1989). The 2009-2010 Karonga earthquake sequence, in the north basin of Lake Malawi, revealed the important role that hangingwall faults play in early stage rifting (Gaherty et al., 2010, 2012). Initial studies did not reveal whether this earthquake sequence represents migration of fault activity away from the border fault or the release of stresses within the hangingwall (Biggs et al., 2010). The Karonga fault has been shown to be an oblique-slip fault with a dominant dip-slip component, which is interpreted to mean that the stress-field of the Rukwa-Livingstone fault zone does not continue south in the Malawi Rift System (Macheyeki et al., 2015).

\subsection{Lake Malawi}

Lake Malawi today is $580 \mathrm{~km}$ long, 25-80 km wide and up to $700 \mathrm{~m}$ deep (Fig. 2b). Twenty-four extreme lowstands, with lake levels dropping more than $200 \mathrm{~m}$ below the present hydrologically open conditions are documented for the last 1.3 m.y. (Lyons et al., 2015). During the most 
extreme lowstands, Lake Malawi was reduced to two hydrologically isolated basins (Lyons et al., 2015).

Up to $4 \mathrm{~km}$ of Cenozoic sediments (Scholz et al., 1989) were deposited over Carboniferous to Cretaceous rocks and Precambrian basement (Contreras et al., 2000). Lake Malawi contains three half-graben basins (Fig. 2b) identified through field investigations and remote sensing (Mohr, 1973; Ebinger et al., 1987 and references therein) and multifold seismic profiles (e.g. Scholz et al., 1989; Specht and Rosendahl, 1989). A structural high separates the northeast-tilting north basin from the westward-tilting central basin but evidence for a structural high between the central and south basins is not present (Specht and Rosendahl, 1989). The south basin tilts eastward toward the sublacustrine Likoma Platform (Specht and Rosendahl, 1989).

\subsection{Border Fault System}

The central basin border fault system is an east-dipping system with at least $1 \mathrm{~km}$ of footwall relief above the western shore of the lake. Its footwall is part of the Mesoproterozoic Irumide Belt (Fritz et al., 2013). The border fault system is $\sim 120 \mathrm{~km}$ long and consists of three segments

(Fig. 2c). The sublacustrine portion of the central segment, mapped from high-resolution seismic data, is $\sim 58 \mathrm{~km}$ long. The northern segment is $\sim 42 \mathrm{~km}$ long and forms a predominantly sublacustrine relay ramp that carries sediments from the South Rukuru River into the deepest part of Lake Malawi. The south segment is mapped from older, lower-resolution basin-scale reflection seismic data and is $\sim 42 \mathrm{~km}$ long. Reflection seismic studies in East African rift basins have interpreted boundary faults to approach their maximum length through linkage of small faults in the early stages of rifting (Morley, 1999). 
Seismic sequences previously identified in the central basin (Scholz et al., 1989; Flannery and Rosendahl, 1990) were the basis of a prior study about stratigraphic throw versus along-strike distance (T-x) on the central-basin border-fault segments (Contreras et al., 2000). Ages originally assigned to these sequences from correlations with onshore data (Ebinger et al., 1993; Contreras et al., 2000) will be significantly refined for our work using the age model from the 2005 scientific drilling project located in the study area (Table 1).

\subsection{Study Area}

Our study area is a fault-bounded sub-basin on the southeast edge of the Lipichili Fault Zone (LFZ) in the central basin of Lake Malawi (Fig. 3a). Faults were mapped in a $730 \mathrm{~km}^{2}$ region and horizons over $\sim 320 \mathrm{~km}^{2}$. The structurally complex fault zone (Fig. 3b) on the northwest side of the study area consists of closely-spaced east- and west-dipping faults. This fault zone has a total length of approximately $28 \mathrm{~km}$ (Fig. 3a). Ten km of that length is the southern north-south striking part while the remaining $18 \mathrm{~km}$ strike northeast-southwest. The eastern edge of the study area is an east-dipping fault array that marks the transition between two major tilted blocks in the central basin (Fig. 3b).

Previous reflection seismic studies in Lake Malawi have focused on the distribution of coarsegrained facies in the central basin (Soreghan et al., 1999; Lyons et al., 2011). Of the five seismic facies described in the central basin by Lyons et al (2011), the hemipelagic drape facies, consisting of "continuous reflections ... blanketing or onlapping pre-existing features on the lake floor" (Lyons et al., $2011 \mathrm{p} 24$ ), is the principal one observed throughout the study area over the last 1.3 million years (Lyons et al., 2011, 2015). 
The hemipelagic drape facies is common away from areas of recent gravity-flow deposition (Soreghan et al., 1999) and its widespread occurrence in this region (Fig. 4) was one of the reasons for locating the 2005 drillsite in this sub-basin (Scholz et al., 2011a). The LFZ acts as a barrier, preventing coarse-grained sediments from the South Rukuru River, the closest major river to the drillsite (Fig. 2c), from entering this part of the sub-basin. The drillsite is not in the hangingwall of any faults (Fig 4a) and therefore sedimentation at this site reflects average basin conditions rather than any local effects (Scholz et al., 2011a) and a continuous sedimentation record is preserved here (Lyons et al., 2015).

Core studies of this seismic facies at other locations in the central basin suggest it is comprised of predominantly clay- and silt-sized sediments with some sandy intervals (Soreghan et al., 1999; Wells et al., 1999). Studies of the 2005 drillsite core identified four facies: 1) homogeneous to sparsely-laminated mud, 2) massive to laminated carbonate-rich mud, 3) finely laminated organic-rich mud, and 4) massive-laminated fine-medium sand (Scholz et al., 2011b).

\section{Methods}

\subsection{Seismic acquisition parameters}

In the 1980s, Project PROBE of Duke University acquired over $3500 \mathrm{~km}$ of 6-second, 24channel seismic reflection data on a reconnaissance grid over the entire lake (Rosendahl, 1986; Scholz and Rosendahl, 1988; Scholz et al., 1989). High resolution single-channel seismic acquisition programs in 1992 and 1995 acquired over $2500 \mathrm{~km}$ of 2D seismic lines in the central basin to characterize lacustrine deltas (Scholz, 1995) and sublacustrine fan systems (e.g. Soreghan et al., 1999). These profiles form a grid with 2-km line spacing, and extend over $~ 100$ $\mathrm{km}$ of the length of the central basin. A further $\sim 800 \mathrm{~km}$ of single-channel seismic data was 
acquired in the central basin in 2001 (Lyons et al., 2011). Detailed acquisition parameters for these datasets are in Table 2.

\subsection{Seismic processing}

The 1980s vintage Project PROBE data provide the basin-scale framework for this study, particularly in regions where high-resolution coverage is absent. Structures and sequences in the central basin are interpreted on Kirchhoff prestack-time-migrated sections given that the limited velocity control of the high-resolution datasets prevented rigorous depth conversion of the seismic data.

Post-stack migration of 1995 and 2001 vintage lines in the study area (Fig. 3) was completed using ProMax ${ }^{\mathrm{TM}}$ software. Algorithms with simple velocity models were used to migrate highresolution single-channel seismic profiles. A qualitative assessment of constant-velocity frequency-wavenumber $(\mathrm{FK})$ migration at several velocities was used to develop a layer-cake velocity model for FK-migration of eleven 1995 high-resolution lines. Constant-velocity FKmigration and FX-deconvolution was performed on eighteen 2001 lines.

\subsection{Seismic interpretation}

Ten horizons were defined in the study area (Figs. 4, 5), with the deepest horizon occurring just above the maximum depth of core 1B from the 2005 Lake Malawi Scientific Drilling Project (Scholz et al., 2006). Laterally continuous reflections were chosen for horizon interpretation. These horizons, and the chronostratigraphic sequences between them, are the foundation of the syntectonic depositional analysis presented here. 
The reprocessed high-resolution seismic lines in the study area form an orthogonal grid with 2-4 $\mathrm{km}$ spacing between parallel lines. Side-by-side seismic displays comparing the shape and depth of the fault segments, the horizon offsets, and apparent fault dips, combined with map positions permitted correlation of fault segments on adjacent seismic profiles. Many uncorrelated fault segments, some with significant displacement, are found in the study area, particularly in the LFZ. However, for simplicity they are omitted from the consideration and the maps for the study area.

\subsection{Core-to-seismic correlation}

Velocities for time-depth calculations at the drillsite were derived from unpublished multifold seismic data, as no downhole acoustic logs or check-shot survey data are available from Malawi Drilling Project Hole 1B. A whole-core p-wave velocity log from the drillcore was used to tie the upper $200 \mathrm{~m}$ of core to the seismic by Lyons et al (2011), however this log was not satisfactory at greater depths and is not used here.

Stacking velocities from a 30 -fold multichannel reflection seismic profile passing through the drillsite were converted to interval velocity in ProMax ${ }^{\mathrm{TM}}$ using a smoothed gradient algorithm instead of the Dix Equation. This curve was used with the whole-core density log to create a new synthetic seismogram for the entire length of the core (Fig. 5). It was tied to the seismic data, and the resulting edited time-depth curve was used to convert the seismic horizon times at the drillsite to depth. Note that the drillcore does not penetrate enough of the seismic section to be used for depth conversion of the seismic data (Fig. 4a), nor does it penetrate the base of the two oldest sequences identified in the PROBE seismic data (Scholz et al., 1989; Flannery and Rosendahl, 1990). 


\subsection{Age model}

The age model from the central basin drillsite is a key component of this study. The computed horizon ages are used to quantify stratal accumulation rates. Accordingly, this location also serves as a reference point for stratigraphic interpretation. The age model is compiled from a combination of 14C, OSL, Ar-Ar, ash and paleomagnetic sources (Lyons et al., 2015). Horizon depths calculated from the seismic data at the drillsite are dated using the age model equations (R. Lyons, pers. comm.) derived from the dated drillcore. Using the average stratal accumulation rate over the length of the drillcore $(427 \mathrm{~ms} / \mathrm{m} . \mathrm{y}$.) and the thickness of the sedimentary sequences at the drillsite, the minimum age of the base of the sedimentary package (c.f. Dawers and Underhill, 2000) in the central basin is estimated to be $\sim 4.6 \mathrm{Ma}$. Our estimated age of the base of the sedimentary sequence is significantly younger than the maximum age interpreted by Contreras et al. (2000). The Contreras et al. (2000) age is the same for the north and central basins, however adjacent half-grabens many not undergo a synchronous structural evolution (Gawthorpe and Hurst, 1993) so the same age is not expected for both basins.

\subsection{Syndepositional Fault Analysis}

The analysis of syndepositional faulting in the study area was conducted in the time domain, because the single drillsite used to convert horizon times to depth at the drillsite is not sufficient well control for depth-conversion of the seismic data. Baudon and Cartwright (2008a) used a 3D seismic survey with some well control to compare syndepositional fault analysis in two-way travel time and in depth, and they found very little distortion between the two. Furthermore, they estimated that the error in the throw values was approximately equal to the sample rate of the seismic data. Consequently, other authors have used the same assumption (e.g. Carruthers et al., 
2013). Osagiede et al (2014) showed that throw gradient calculations are strongly affected by vertical seismic resolution, with error being greater for lesser seismic resolutions. The sample rate in the high-resolution seismic data used for this study is $0.5 \mathrm{~ms}$, and so we assume this interval equals the error in our throw calculations.

The footwall and hangingwall cutoff times for the horizons form the basis of all calculations. These cutoffs are observed on seismic data when 1) the true fault geometry is imaged, 2) the horizons can be accurately correlated from the footwall to the hangingwall, and 3) the thickness of the hangingwall and footwall units can be constrained (Osagiede et al., 2014). In this study, horizon cutoff times are picked manually. In most cases, the horizon cutoffs can be interpreted right at the fault (Fig. 4), and very little projection is required (c.f. Whipp et al., 2014; Duffy et al., 2015; Reeve et al., 2015), except where apparent fault drag is present (Fig. 4d).

The lack of coherent reflectors within the LFZ (Fig. 4c, d) is attributed to a combination of ductile deformation between closely-spaced faults and difficulty correctly migrating singlechannel seismic data in time. Poor resolution within the LFZ prevents T-z analysis of the west side of this fault zone.

We restrict our analysis to locations within the 600-m lowstand contour (Fig. 3) of Lyons et al (2011) to minimize the effect of subaerial exposure during lowstands on sediment preservation (Scholz et al., 2007). The true thicknesses of sequences are not preserved if prolonged subaerial exposure leads to erosion (Shanmugam, 1988). Subaerial exposure has been observed southeast of the study area, above the 600-m lowstand contour.

The orientation at which a seismic profile intersects a fault affects our ability to resolve both the fault and the horizons in the hangingwall and footwall of the fault. As the orientation of a seismic 
line approaches the same azimuth as the fault strike, the fault may appear vertically segmented (Fig. 6a) even if the fault is imaged as a single vertical segment on seismic lines at angles closer to the dip direction of the fault (Fig. $6 \mathrm{~b}$ and $6 \mathrm{c}$ ). Throw-depth profiles are also affected by the angle at which the seismic line intersects the fault. The measured vertical separation (stratigraphic throw) is less when the seismic line is closer to parallel to the fault strike. For example, the angle between the seismic line and the fault shown in Fig. $6 \mathrm{a}$ is $\sim 23^{\circ}$. None of the locations used in this study are on seismic lines that intersect a fault at such a small angle - the average angle of intersection in this study is $68^{\circ}$. The similarity between the T-z profiles for this fault on the other two seismic lines (Fig. 6d, 6e) shows that seismic lines intersecting the fault at angles between $75^{\circ}-114^{\circ}$ will have similar T-z profiles. Still, the range of angles that will give similar T-z profiles may be larger than shown in this example.

Differential compaction on the hangingwall and the footwall of a fault will influence syndepositional fault analysis. Studies of displacement and compaction on syndepositional faults indicate that compaction typically accounts for less than a $20 \%$ reduction in stratal thickness and this maximum value occurs when strata have been buried more than $5 \mathrm{~km}$ following deposition at or near the free surface (Taylor et al., 2008). Burial depths this great are not found in our study area for the sedimentary sequence that was deposited in the last 1.3 million years. The changes in stratal thickness due to compaction will affect absolute throw, but not the patterns of throw variation (Jackson and Rotevatn, 2013) we are investigating here. Similar studies have omitted the differential compaction correction because the porosity-depth constraints needed for decompaction are not available (e.g. Giba et al., 2012; Jackson and Rotevatn, 2013) or because with small throws, the effect of differential compaction is negligible (e.g. Cartwright et al., 1998; 
Baudon and Cartwright, 2008a). Accordingly, no correction for differential compaction is applied in this study.

\subsubsection{Thickness maps}

We use time isochore maps of the chronostratigraphic sequences to study the basin morphology. Thick zones in these maps represent locations where accommodation space was filled during deposition of that sequence. We assume that all accommodation space was created by relative subsidence of the hangingwall blocks of the faults in the area. The isochore maps are generated in Decision Space ${ }^{\circledR}$ by gridding the horizons then subtracting the TWTT of the upper horizon grid from the TWTT of the lower horizon grid.

\subsubsection{Stratal accumulation rates}

Stratal accumulation rate (SAR) measured in this study is the ratio between the thickness (ms two-way travel time) and the duration (thousand years) of the sequence (Eq. (1)):

$$
S A R=\frac{T W T T_{L}-T W T T_{U}}{A g e_{L}-A g e_{U}}
$$

where TWTT $_{L}$ is the cutoff time of the lower horizon, TWTT $_{U}$ is the cutoff time of the upper horizon, $\mathrm{Age}_{\mathrm{L}}$ is the age of the lower horizon and $\mathrm{Age}_{\mathrm{U}}$ is the age of the horizon. A schematic illustration is found in Figure 7. SARs for each sequence were calculated at the 2005 drillsite and in the hangingwall and footwall of faults at 25 locations (Fig. 3).

\subsubsection{The occurrence of growth strata in mud}

Polycyclic fault motion observed by Cartwright et al. (1998) may not differentiate between sedimentary cycles (alternating sand and mud deposition) and tectonically controlled-intervals 
(Castelltort et al., 2004a). Castelltort et al. (2004a, 2004b) and Pochat et al. (2004, 2009) suggested that basin topography is only filled by sand, and that during mud deposition, basin topography is covered in a layer of uniform thickness. If this interpretation is the case, thickness variations between the hangingwall and footwall of an actively displacing fault will only be observed during sand deposition (Castelltort et al., 2004a, 2004b). Recent studies have shown, however, that mud transportation is not restricted to the suspended load (e.g. Macquaker et al., 2010; Bohacs et al., 2014; Lazar et al., 2015), as for example, evidence exists for transport of fine-grained (hemipelagic) sediments within the Santa Barbara Basin of California (Thornton, 1984). Growth strata have also been identified in lacustrine muds in Tibet (Heermance et al., 2013) and Japan (Muraoka and Kamata, 1983) and they are well-preserved in the hangingwall of the faults in this study area.

\subsubsection{T-z plots}

The throw versus depth (T-z) method has been used to study fault evolution using 3D reflection seismic data in basins worldwide, including the Eastern Mediterranean (e.g. Baudon and Cartwright, 2008a, 2008b), the North Sea (e.g. Carruthers et al., 2013; Duffy et al., 2015), the Suez Rift (e.g. Jackson and Rotevatn, 2013), the Gulf of Mexico (e.g. Mansfield and Cartwright, 1996) and offshore Brazil (e.g. Omosanya and Alves, 2014). However, the method can also be used for interpreting 2D seismic (Cartwright et al., 1998; Tearpock and Bischke, 2002).

Stratigraphic throw is the vertical separation between hangingwall and footwall cut-offs of a stratigraphic horizon and is used as a proxy for fault displacement when kinematic indicators are not available (Whipp et al., 2014). By plotting stratigraphic throw (T) vs. depth (z) at several locations, variations in relative fault displacement can be quantified. Here, depth is measured in 
two-way travel-time (TWTT), so that the relative changes in stratigraphic throw needed for this study can be interpreted in TWTT.

We calculate stratigraphic throw $(\mathrm{T})$ on a horizon by measuring the vertical separation, in TWTT, between the hangingwall and footwall cutoffs for the horizon (Eq. (2)):

$$
T=T W T T_{U^{\prime}}-T W T T_{U}
$$

where $\mathrm{TWTT}_{\mathrm{U}}$ is the hangingwall cutoff time and $\mathrm{TWTT}_{\mathrm{U}^{\prime}}$ is the footwall cutoff time for the same horizon. The depth (z) in a T-z plot is the depth (in TWTT) to the midpoint of the vertical separation (Eq. (3)):

$$
z=T W T T_{U^{\prime}}-(0.5 \times T) .
$$

Positive T-z profile slope (Fig. 7) indicates fault displacement, null slope indicates fault inactivity, and negative slope has been interpreted to indicate fault inversion, erosion, or downdip fault linkage, with a throw minima corresponding to a point of linkage (Mansfield and Cartwright, 1996; Cartwright et al., 1998; Castelltort et al., 2004b).

\subsubsection{T-x plots}

We do not identify any faults that are continuous along the entire along-strike length of the LFZ, however along-strike variations in a fault array can be studied by summing the displacements at a set of along-strike positions for a fault or faults (Walsh and Watterson, 1991; Trudgill and Cartwright, 1994; e.g. Dawers and Anders, 1995; Schlische, 1995). This kind of cumulative lateral throw would be biased in our study due to the different number of faults with horizon cutoffs at each along-strike position within the array. Instead, we average the stratigraphic throw and plot the lateral averages against along-strike distance to create T-x plots. Displacement 
minima on T-x plots (Fig 7c, d) are interpreted to represent points of along-strike linkage between fault segments (Peacock and Sanderson, 1991; Cartwright et al., 1995; Dawers and Anders, 1995; e.g. Whipp et al., 2014). Spacing of our data (minimum of $2 \mathrm{~km}$ spacing between adjacent along-strike points) results in distortion of the T-x plots caused by too few data points, i.e. aliasing, and prevents detailed analysis of along-strike linkage. Still, we use T-x plots to examine changes in the total length of the fault array over time. If faults propagate according to the radial propagation model (e.g. Cartwright et al., 1995), the oldest T-x profile for the same fault will be much narrower than the youngest profile (Fig. 7c).

\section{Syndepositional Fault Analysis}

In the absence of 3D seismic data or ground-truthed kinematic indicators, assumptions about fault slip are required. We assume that the faults in this study have been dominantly dip-slip over the last 1.3 m.y. However, negative T-z slopes with this assumption could reflect a reduction or a lack of the dip-slip component of faulting. If the lateral-slip component becomes greater, interpreting tectonic controls on thickness changes becomes complicated because the amount of accommodation space created can be reduced despite continuous fault motion (Koning et al., 2013).

Growth strata record both a sedimentary and a tectonic cycle (Castelltort et al., 2004a).

Interpreting tectonic controls on growth strata requires an assumption that sediments will fill accommodation space created by fault displacement. This approach is referred to as the "fill-tothe-top" assumption (Cartwright et al., 1998), and it is not valid unless: 1) lithological changes in sediment supply are accounted for (Castelltort et al., 2004b); 2) sedimentation rates are constant throughout the study area (Pochat et al., 2009); and 3) climate-driven changes in sediment 
volume are accounted for (Castelltort et al., 2004a). To account for lithological changes over the last 1.3 m.y. we note that even when lake levels were much lower than modern levels, this part of the basin was dominated by fine-grained, hemipelagic sedimentation (Lyons et al., 2011, 2015).

We use SAR to approximate sedimentation rate here. In Figure 8, we show the drillsite SAR, mean footwall SAR and mean hangingwall SAR for each sequence. If sedimentation is constant and fault displacement produces thickness variations between the hangingwall and footwall of a fault, the mean hangingwall SAR should be higher than the mean footwall SAR. This is true everywhere except Sequence 1. Furthermore, if sedimentation rates are constant, we expect the SAR at the drillsite to be within one standard deviation of the mean footwall and hangingwall SARs. This is true everywhere except for Sequences 9 and 7.

When our chronostratigraphic sequences are plotted with the lake level curve from Lyons et al (Lyons et al., 2015), we observe that lake level is close to $600 \mathrm{~m}$ below modern levels for most of Sequence 1 and 2 (Fig. 8). The low lake levels pervasive through Sequence 1 indicate it was a time when sediment focusing effects, the redistribution of sediment into the deepest part of the basin, may have driven higher sediment accumulation rates in the basin (Lehman, 1975). Verschuren (1999) shows that during times of low lake level, wave action and deep mixing can focus sediments into a smaller depositional area. Therefore, during Sequence 1, the high footwall SARs may be attributed to local variations in sedimentation and the "fill-to-the-top" assumption may not hold. During Sequences 3-6, periods where lake level drops more than $400 \mathrm{~m}$ below modern lake level are brief compared to the length of the sequences. This transition reflects the hydroclimatic changes that followed the Mid-Pleistocene Transition (Lyons et al., 2015). During Sequence 9, a prolonged megadrought interval (Scholz et al., 2007; Lyons et al., 2011) begins. 
This is interpreted to have led to an increase in stratal accumulation rates via sediment focusing effects.

Finally, we consider climate-driven changes in sediment volume. When the scale of observation, i.e. the duration of the chronostratigraphic sequences, is much greater than the rate of change of lake level, we assume the observed signal is driven by tectonics. However, when the scale of observation is closer to the scale of climatic cycles, the fill-to-the-top assumption may not be valid (Castelltort et al., 2004a). Using the approximate duration of lake cycles estimated by Lyons et al (Lyons et al., 2015), we measured the number of lake cycles per sequence (Table 3). Before the Mid-Pleistocene Transition (MPT), there are more than ten cycles per sequence; following the MPT, the number of cycles per sequence decreases. During Sequence 7, when the number of cycles per sequence drops to 2.1 , the scale of observation is too close to the scale of climatic cycles for the fill-to-the-top assumption to be valid, and the anomalously high footwall SAR during this time reflects this condition.

\subsection{Sub-basin configuration}

The isochore map for Sequence $1(1176-1308 \mathrm{ka})$ has a thick zone approximately parallel to the LFZ, highlighted where the isochore values are greater than the mean (Fig. 9). This depocenter is present on the isochore maps for all subsequent sequences. We interpret this thick zone (Fig. 4b, c, d) as the syncline hinge of a longitudinal fold (c.f. Schlische, 1995), and the fact that it is has been present since 1.3 Ma is an indication that the structural configuration of the study area has been consistent, and was established by $\sim 1.3 \mathrm{Ma}$, if not earlier.

\subsection{Growth on the intrabasin faults}


Stratigraphic throw on fault IB-E01 decreases toward the fault tip in the northwest and increases with depth at each location along the fault, until the end of Sequence 6 (Fig. 10a). This increase of throw with depth is indicative of an active, surface-breaking fault (e.g. Baudon and Cartwright, 2008a, 2008b; Duffy et al., 2015). The subsequent null and negative slopes all occur during times when high stratal accumulation rates correlates with low lake level, so that the fillto-the-top assumption may not be valid.

At the southern end of fault IB-E02, at position 9 (Fig. 10b), a negative T-z slope occurs during Sequence 1, when we have noted that footwall sediment accumulation rates are on average greater than hangingwall sedimentation rates due to local variations in sediment accumulation caused by sediment focusing effects. Negative T-z slopes are observed at all positions along fault IB-E02, including during Sequences 3, 4, 6, and 8, during sequences when we interpret the "fillto-the-top" model to be valid. For these cases, a tectonic source for the negative slopes is considered in section 5.1. The lack of data for Sequence 1-5 at position 6 is because no horizons below this can be interpreted in the footwall of this fault due to seismic data quality.

Maximum throw is expected to occur at the center of each normal fault (Peacock and Sanderson, 1991; Cartwright et al., 1995; Dawers and Anders, 1995; Whipp et al., 2014). This behavior is evident in the T-z profiles for fault IB-E02, where stratigraphic throw is always greatest at position 8, near the middle of the along-strike length of the fault (Fig. 3). More along-strike samples would be needed to use this method to pinpoint the exact centre of the fault. By the same arguments, the along-strike center of fault IB-E01 is expected between positions 4 and 5 or to southeast beyond the study area.

\subsection{Growth in the Lipichili Fault Zone (LFZ)}

Page 21 of 43 
The lack of data at the north end of the LFZ for the oldest sequences (Fig. 11) is a reflection of horizon resolution decreasing with depth along that seismic line (Fig. 4c), rather than a lack of fault displacement during that time. Positive T-z slope is observed on at least one fault segment within the LFZ during every sequence (Fig. 11a) and laterally-averaged throw is largest at the south end of the LFZ for Sequences 1 to 4 (Fig. 11b).

\section{Discussion and Conclusions}

\subsection{Fault Propagation}

The null T-z profile slopes during times when we interpret the fill-to-the-top model to be valid can be explained by shadow zones described by Gupta et al. (1998) and Cowie (1998). Elastic strain perturbations in the rocks surrounding a fault rupture result in the establishment of zones where stress either increases or is relaxed (Gupta et al., 1998). When the zones from adjacent faults overlap, feedbacks develop, such that rupture in a zone of overlapping shadow (relaxed stress) zones results in a decrease of stresses (Cowie et al., 2000). Overlapping shadow zones can result in a cessation of fault activity (Gupta et al., 1998) which corresponds to a null slope on the T-z profile.

The T-x profiles for the LFZ do not exhibit the pattern expected if the array had grown through radial propagation (Fig. 7c, Fig 11b). We do not see the expected decreases in throw at the points of segment linkage (Fig. 7d, Fig. 11b) for faults that grow by segment linkage either, but we attribute this absence to spatial aliasing in the T-x profiles rather than the absence of this style of fault propagation.

Fault activity ceased at the northwest end of fault IB-E01 as early as $1177 \mathrm{ka}$ (i.e. the end of Sequence 1). If this fault grew according to the radial propagation model (Cartwright et al., 
1995), fault activity on each end of the fault would initiate later than at the center of the fault. Similarly, for fault IB-E02 and the LFZ, we would expect null slopes in the T-z profiles at the ends of the fault/array during the oldest sequences, with positive or negative slopes occurring once faulting has initiated. We do not see these expected patterns, therefore both intrabasin faults and the LFZ must have established their current lengths by at least 1.3 Ma.

Morley (1999) showed that border fault systems in many basins in the EARS established their length early through the linkage of small faults. Modeling results constrained by observations in the Timor Sea by Walsh et al (2002) show the same thing. Walsh et al. suggested rapid establishment of fault length is the result of reactivation of pre-rift fabric. The fault arrays in the Mesozoic continental rift of southern South Africa are also controlled by an older reactivated fault system (Paton, 2006).

We cannot constrain whether pre-existing structures were reactivated in our study area, however given the rift's location in a Proterozoic mobile belt, we hypothesize that pre-rift fabric is of primary importance. The map pattern of the northern segments of the LFZ is consistent with map patterns expected for a localized reorientation of the stress field resulting from pre-rift basement structures (Morley, 2010; Reeve et al., 2015).

\subsection{Fault Migration}

We find that the hangingwall faults of Lake Malawi's central basin experienced continuous fault activity over the last $\sim 1.3 \mathrm{Ma}$. This activity was synchronous with the establishment of the central basin border fault system as a fully linked system during the Mbamba Sequence (Contreras et al., 2000), which we date at $\sim 1.1 \mathrm{Ma}-\sim 249 \mathrm{ka}$. Prior to this linkage, from $\sim 3.4 \mathrm{Ma}$ to $\sim 1.1 \mathrm{Ma}$, Contreras et al. noted that the south segment of the border fault system was the most 
active. The south segment, as mapped by Contreras et al, includes the eastern side of the LFZ (Contreras et al., 2000, Fig. 4), which supports our interpretation that the current bathymetric configuration was established before 1.3 Ma. From 57 ka to the present (i.e. sequence 10), activity on many of the sub-basin faults ceased, evidenced by continuous reflections overlying the tips of the faults in the reflection seismic profiles, although modern earthquake records indicate some faults in the central basin are still active (Delvaux and Barth, 2010).

For models of basinward migration of extensional faulting (Agostini et al., 2009; Corti et al., 2010, 2013), the border fault is abandoned when it can no longer accommodate extension (Corti et al., 2013). According to these modeling results, rifts with thick crusts and slow extension rates should experience a slow transition between the Boundary Faults and Internal Faults Stages. Regional extension rates estimated from present kinematic studies are as low as $1.5-2.2$ mm/year (Saria et al., 2014). In the Corti et al. (2013) model with a comparable velocity of extension, it will take 10.5 Ma for this transition to occur. Reflection seismic data that image much deeper are needed to further constrain the timing of the hangingwall fault establishment; however it was at least 1.3 Ma, only 3.3 million years from our estimated minimum onset of rifting. This timing is earlier than modeling results would predict and is coincident with displacement on the border fault system.

\subsection{Implications}

Basinward migration of normal faults is attributed to a need to transfer strain/accommodate extension once a maximum fault displacement-Length (d-L) relationship is reached (Goldsworthy and Jackson, 2001; Corti et al., 2013). In basins with pre-existing faults, strain is localized on faults that establish their length early in the basin's evolution (Walsh et al., 2002). In 
southern South Africa, this strain localization occurred on the border faults and no hangingwall faults are observed (Paton, 2006). On the other hand, our study is an example strain localization occurring in the hangingwall faults, which are active from an early stage in the basin's development. One difference between our study and the Paton (2006) study is that our fault segments are en echelon, whereas the southern South African fault segments are linear. This difference is likely the result of different types of pre-rift structures. The Mesozoic South African rifts are underlain by a fold belt parallel to the rift orientation (Paton, 2006) whereas the most likely pre-rift fabrics in our study area are shear zones oblique to the rift orientation (Fritz et al., 2013; Laó-Dávila et al., 2015). We conclude that orientation of pre-rift fabrics with respect to the extension direction controls whether or not strain will be localized on border faults or hangingwall faults. In either case, this early strain localization negates the need for border fault migration.

Where basinward migration occurs, such as the Gediz Graben in the Aegean Sea (Dart et al., 1995), the oldest synrift strata, which record the onset of rifting, are recycled when they become part of the uplifted footwall of the newer border faults. Further studies in the basins where border fault migration is not observed, like central basin of the Malawi Rift, will have more continuous and complete records of basin fill than those basins where border fault migration occurs. The intrabasin structures discussed here, including the LFZ and discrete hangingwall faults, have had major influence in partitioning sediment pathways between sub-basins within this large rift segment for most of the basin evolution. As a result, sediments accumulate in the bathymetric lows maintained by activity on these structures rather than prograding across the width of the basin and onlapping the flexural margin. While the central basin of the Malawi Rift is an extreme 
example of this behavior, basin filling models must account for complex hangingwall geometries that persist throughout the basin evolution.

\subsection{Summary}

Our study shows that syndepositional fault analysis can be used to study fault evolution in lacustrine muds. Using stratal accumulation rates as a proxy for sedimentation rates, we are able to estimate when climate-driven sedimentation rate fluctuations are contributing to observed changes in stratal thicknesses through a fault zone. For most of the last $1.3 \mathrm{~m} . \mathrm{y}$. , we attribute the changes in stratal thickness across the fault zones to tectonically-driven creation of accommodation space.

The current basin configuration was probably established by $\sim 4.6 \mathrm{Ma}$ and certainly well before 1.3 Ma. We conclude that the hangingwall faults in the central basin of the Malawi Rift established their current length through segment linkage. These linkages occurred early in the basin's development as a result of strain localization related to pre-rift fabric. Since at least 1.3 $\mathrm{Ma}$, and possibly earlier, the main depocenter for the central basin has been adjacent to the central segment, and a smaller depocenter formed east of the LFZ because the faults in this array accumulated displacement at the same time as the border fault. No fault migration is observed over the last 1.3 million years.

Models for continental rift development that involve migration of fault activity away from the border fault system are not applicable at this stage of the evolution of this rift, and may not be applicable in rifts where pre-rift fabric causes localized strain migration at an early stage of fault development. This style of deformation should be considered in other basins where a pre-rift 
fabric may facilitate the rapid development of hangingwall faults, which has implications for sediment distribution within the sub-basins of the half-graben. 


\section{Acknowledgements}

We thank reviewers Atle Rotevatn and Oliver Duffy and Editor William M. Dunne for their constructive reviews of this manuscript. We thank Jeff Karson, Dan Curewitz, Donna Shillington and Rob Moucha for their discussions and feedback on earlier drafts of the manuscript. ProMax processing software and Decision Space interpretation software made available to Syracuse University through a software grant from Landmark Solutions. Financial support for the project was provided from the U.S. National Science Foundation grant EAR1110882 to CAS, and from sponsors of the Syracuse University Lacustrine Rift Basin Industrial Associates. 
References

Agostini, A., Corti, G., Zeoli, A., Mulugeta, G., 2009. Evolution, pattern, and partitioning of deformation during oblique continental rifting: Inferences from lithospheric-scale centrifuge models. Geochemistry, Geophys. Geosystems 10. doi:10.1029/2009GC002676

Baudon, C., Cartwright, J., 2008a. 3D seismic characterisation of an array of blind normal faults in the Levant Basin, Eastern Mediterranean. J. Struct. Geol. 30, 746-760. doi:10.1016/j.jsg.2007.12.008

Baudon, C., Cartwright, J., 2008b. Early stage evolution of growth faults: 3D seismic insights from the Levant Basin, Eastern Mediterranean. J. Struct. Geol. 30, 888-898. doi:10.1016/j.jsg.2008.02.019

Biggs, J., Nissen, E., Craig, T., Jackson, J., Robinson, D.P., 2010. Breaking up the hanging wall of a rift-border fault: The 2009 Karonga earthquakes, Malawi. Geophys. Res. Lett. 37, L11305. doi:10.1029/2010GL043179

Bohacs, K., Lazar, O.R., Demko, T.M., 2014. Parasequence types in shelfal mudstone strata-Quantitative observations of lithofacies and stacking patterns, and conceptual link to modern depositional regimes. Geology 42, 131-134. doi:10.1130/G35089.1

Burke, K., Gunnell, Y., 2008. The African erosion surface: a continental-scale synthesis of geomorphology, tectonics, and environmental change over the past 180 million years. Geol. Soc. Am. Mem. 201.

Carruthers, D., Cartwright, J., Jackson, M., Schutjens, P., 2013. Origin and timing of layer-bound radial faulting around north sea salt stocks: New insights into the evolving stress state around rising diapirs. Mar. Pet. Geol. 48, 130-148. doi:10.1016/j.marpetgeo.2013.08.001

Cartwright, J., Bouroullec, R., James, D., Johnson, H., 1998. Polycyclic motion history of some Gulf Coast growth faults from high-resolution displacement analysis. Geology 26, 819-822. doi:10.1130/0091-7613(1998)026<0819:PMHOSG>2.3.CO;2

Cartwright, J., Trudgill, B.D., Mansfield, C.S., 1995. Fault growth by segment linkage: an explanation for scatter in maximum displacement and trace length data from the Canyonlands Grabens of SE Utah. J. Struct. Geol. 17, 1319-1326. doi:10.1016/01918141(95)00033-A

Castelltort, S., Pochat, S., Van Den Driessche, J., 2004a. How reliable are growth strata in interpreting short-term (10s to 100s ka) growth structures kinematics? Comptes Rendus Geosci. 336, 151-158. doi:10.1016/j.crte.2003.10.020

Castelltort, S., Pochat, S., Van Den Driessche, J., 2004b. Using T-Z plots as a graphical method to infer lithological variations from growth strata. J. Struct. Geol. 26, 1425-1432. doi:10.1016/j.jsg.2004.01.002

Chorowicz, J., 2005. The East African rift system. J. African Earth Sci. 43, 379-410. doi:10.1016/j.jafrearsci.2005.07.019 
Cohen, A., Soreghan, M., Scholz, C., 1993. Estimating the age of formation of lakes: an example from Lake Tanganyika, East African Rift system. Geology. doi:10.1130/00917613(1993)021<0511

Contreras, J., Anders, M., Scholz, C., 2000. Growth of a normal fault system: observations from the Lake Malawi basin of the East African Rift. J. Struct. Geol. 22, 159-168. doi:10.1016/S0191-8141(99)00157-1

Corti, G., 2009. Continental rift evolution: From rift initiation to incipient break-up in the Main Ethiopian Rift, East Africa. Earth-Science Rev. 96, 1-53. doi:10.1016/j.earscirev.2009.06.005

Corti, G., 2008. Control of rift obliquity on the evolution and segmentation of the main Ethiopian rift. Nat. Geosci. 1, 258-262. doi:10.1038/ngeo160

Corti, G., Ranalli, G., Agostini, A., Sokoutis, D., 2013. Inward migration of faulting during continental rifting: Effects of pre-existing lithospheric structure and extension rate. Tectonophysics 594, 137-148. doi:10.1016/j.tecto.2013.03.028

Corti, G., Ranalli, G., Mulugeta, G., Agostini, A., Sani, F., Zugu, A., 2010. Control of the rheological structure of the lithosphere on the inward migration of tectonic activity during continental rifting. Tectonophysics 490, 165-172. doi:10.1016/j.tecto.2010.05.004

Corti, G., Wijk, J. van, Cloetingh, S., Morley, C., 2007. Tectonic inheritance and continental rift architecture: Numerical and analogue models of the East African Rift system. Tectonics 26, 13. doi:10.1029/2006TC002086

Cowie, P., Gupta, S., Dawers, N., 2000. Implications of fault array evolution for synrift depocentre development: insights from a numerical fault growth model. Basin Res. 12, 241-261.

Cowie, P.A., 1998. A healing-reloading feedback control on the growth rate of seismogenic faults. J. Struct. Geol. 20, 1075-1087. doi:10.1016/S0191-8141(98)00034-0

Dart, C., Cohen, H.A., Akyuz, H.S., Barka, A., 1995. Basinward migration of rift-border faults: implications for facies distributions and preservation potential. Geology 23, 69-72. doi:10.1130/0091-7613(1995)023<0069:BMORBF>2.3.CO;2

Dawers, N., Anders, M., 1995. Displacement-length scaling and fault linkage. J. Struct. Geol. 17, 607-614.

Dawers, N., Underhill, J., 2000. The role of fault interaction and linkage in controlling synrift stratigraphic sequences: Late Jurassic, Statfjord East area, northern North Sea. Am. Assoc. Pet. Geol. Bull. 1, 45-64.

Delvaux, D., Barth, A., 2010. African stress pattern from formal inversion of focal mechanism data. Tectonophysics 482, 105-128. doi:10.1016/j.tecto.2009.05.009

Duffy, O.B., Bell, R., Jackson, C.A.L., Gawthorpe, R., Whipp, P.S., 2015. Fault growth and interactions in a multiphase rift fault network: Horda Platform, Norwegian North Sea. J. 
Struct. Geol. 80, 99-119. doi:10.1016/j.jsg.2015.08.015

Ebinger, C., 2005. Continental break-up: the East African perspective. Astron. Geophys. 46.

Ebinger, C., Deino, A., Drake, R., Tesha, A., 1989. Chronology of volcanism and rift basin propagation: Rungwe volcanic province, East Africa. J. Geophys. Res. 94, 15785-15803.

Ebinger, C., Deino, A., Tesha, A., Becker, T., Ring, U., 1993. Tectonic controls on rift basin morphology: Evolution of the northern Malawi (Nyasa) Rift. J. Geophys. Res. 98, 17821. doi:10.1029/93JB01392

Ebinger, C., Rosendahl, B., Reynolds, D., 1987. Tectonic model of the Malawi rift, Africa. Tectonophysics 141, 215-235.

Fagereng, Å., 2013. Fault segmentation, deep rift earthquakes and crustal rheology: Insights from the 2009 Karonga sequence and seismicity in the Rukwa-Malawi rift zone. Tectonophysics 601, 216-225. doi:10.1016/j.tecto.2013.05.012

Faulds, J.E., Varga, R., 1998. The role of accommodation zones and transfer zones in the regional segmentation of extended terranes, in: Faulds, J., Stewart, J. (Eds.), Accommodation Zones and Transfer Zones: The Regional Segmentation of the Basin and Range Province. Geological Society of America Special Paper 323, Boulder, Colorado.

Flannery, J., Rosendahl, B., 1990. The seismic stratigraphy of Lake Malawi, Africa: implications for interpreting geological processes in lacustrine rifts. J. African Earth Sci. 10, 519-548.

Fritz, H., Abdelsalam, M., Ali, K., Bingen, B., Collins, A., Fowler, A., Ghebreab, W., Hauzenberger, C., Johnson, P., Kusky, T., Macey, P., Muhongo, S., Stern, R., Viola, G., 2013. Orogen styles in the East African Orogen: A review of the Neoproterozoic to Cambrian tectonic evolution. J. African Earth Sci. 86, 65-106. doi:10.1016/j.jafrearsci.2013.06.004

Gaherty, J., Shillington, D., Kapanje, W., Chindandali, P., Nooner, S., Ebinger, C., Nyblade, A., Kalindekafe, L., Pritchard, M., Scholz, C., 2010. Faulting processes during early-stage rifting: seismicity analysis of the 2009-2010 Northern Malawi earthquake sequence, in: AGU Fall Meeting.

Gaherty, J., Shillington, D., Shuler, A., Mavrommatis, A., Pritchard, M., Lindsey, N., Kapanje, W., Mdala, H., Chindandali, P., Nooner, S., Nyblade, A., 2012. Faulting processes during early-stage rifting: seismic and geodetic analysis of the 2009-2010 Northern Malawi earthquake sequence, in: AGU Fall Meeting.

Gawthorpe, R., Hurst, J.M., 1993. Transfer zones in extensional basins: their structural style and influence on drainage development and stratigraphy. J. Geol. Soc. London 150, 1137-1152. doi:10.1144/gsjgs.150.6.1137

Giba, M., Walsh, J., Nicol, A., 2012. Segmentation and growth of an obliquely reactivated normal fault. J. Struct. Geol. 39, 253-267. doi:10.1016/j.jsg.2012.01.004

Goldsworthy, M., Jackson, J., 2001. Migration of activity within normal fault systems: examples 
from the Quarternary of mainland Greece. J. Struct. Geol. 23, 489-506.

Gupta, S., Cowie, P., Dawers, N., Underhill, J., 1998. A mechanism to explain rift-basin subsidence and stratigraphic patterns through fault-array evolution. Geology 26, 595-598. doi:10.1130/0091-7613(1998)026<0595

Heermance, R. V., Pullen, A., Kapp, P., Garzione, C.N., Bogue, S., Ding, L., Song, P., 2013. Climatic and tectonic controls on sedimentation and erosion during the Pliocene-Quaternary in the Qaidam Basin (China). Geol. Soc. Am. Bull. 125, 833-856. doi:10.1130/B30748.1

Jackson, C.A.L., Rotevatn, A., 2013. 3D seismic analysis of the structure and evolution of a saltinfluenced normal fault zone: A test of competing fault growth models. J. Struct. Geol. 54, 215-234. doi:10.1016/j.jsg.2013.06.012

Koning, D., Graouch, V., Connell, S., Ferguson, J., McIntosh, W., Slate, J., Wan, E., Baldridge, W., 2013. Structure and tectonic evolution of the eastern Espanola Basin, Rio Grande rift, north-central New Mexico, in: Hudson, M., Grauch, V. (Eds.), New Perspectives on Rio Grande Rift Basins: From Tectonics to Groundwater: Geological Society of America Special Paper 494. Geological Society of America, pp. 185-219.

Laó-Dávila, D.A., Al-Salmi, H.S., Abdelsalam, M.G., Atekwana, E.A., 2015. Hierarchical segmentation of the Malawi Rift: The influence of inherited lithospheric heterogeneity and kinematics in the evolution of continental rifts. Tectonics n/a-n/a. doi:10.1002/2015TC003953

Lazar, O.R., Bohacs, K., Macquaker, J.H.S., Schieber, J., Demko, T.M., 2015. Capturing key attributes of fine-grained sedimentary rocks in outcrops, cores, and thin sections: nomenclature and description guidelines. J. Sediment. Res. 85, 230-246.

Lehman, J.T., 1975. Reconstructing the rate of accumulation of lake sediment: The effect of sediment focusing. Quat. Res. doi:10.1016/0033-5894(75)90015-0

Lyons, R., Scholz, C., Buoniconti, M.R., Martin, M.R., 2011. Late Quaternary stratigraphic analysis of the Lake Malawi Rift, East Africa: An integration of drill-core and seismicreflection data. Palaeogeogr. Palaeoclimatol. Palaeoecol. 303, 20-37. doi:10.1016/j.palaeo.2009.04.014

Lyons, R., Scholz, C.A., Cohen, A.S., King, J.W., Brown, E.T., Ivory, S.J., Johnson, T.C., Deino, A.L., Reinthal, P.N., Mcglue, M.M., Blome, M.W., 2015. Continuous 1.3-millionyear record of East African hydroclimate, and implications for patterns of evolution and biodiversity. Proc. Natl. Acad. Sci. 112, 2-7. doi:10.1073/pnas.1512864112

Macheyeki, A.S., Mdala, H., Chapola, L.S., Manhiça, V.J., Chisambi, J., Feitio, P., Ayele, A., Barongo, J., Ferdinand, R.W., Ogubazghi, G., Goitom, B., Hlatywayo, J.D., Kianji, G.K., Marobhe, I., Mulowezi, A., Mutamina, D., Mwano, J.M., Shumba, B., Tumwikirize, I., 2015. Active fault mapping in Karonga-Malawi after the December 19, 2009 Ms 6.2 seismic event. J. African Earth Sci. 102, 233-246. doi:10.1016/j.jafrearsci.2014.10.010

Macquaker, J.H.S., Bentley, S.J., Bohacs, K., 2010. Wave-enhanced sediment-gravity flows and 
mud dispersal across continental shelves: Reappraising sediment transport processes operating in ancient mudstone successions. Geology 38, 947-950. doi:10.1130/G31093.1

Mansfield, C.S., Cartwright, J., 1996. High resolution fault displacement mapping from threedimensional seismic data: evidence for dip linkage during fault growth. J. Struct. Geol. 18, 249-263. doi:10.1016/S0191-8141(96)80048-4

Mohr, P., 1973. ERTS-1 Imagery of Eastern Africa: A first look at the geological structure of selected areas. Smithsonian Astrophysics Observatory Special Report No. 347.

Morley, C., 2010. Stress re-orientation along zones of weak fabrics in rifts: An explanation for pure extension in "oblique" rift segments? Earth Planet. Sci. Lett. 297, 667-673. doi:10.1016/j.eps1.2010.07.022

Morley, C., 1999. Patterns of displacement along large normal faults: implications for basin evolution and fault propagation, based on examples from East Africa. Am. Assoc. Pet. Geol. Bull. 83 (1999), 613-634. doi:10.1306/00AA9C0A-1730-11D7-8645000102C1865D

Morley, C., Nelson, R., Patton, T., Munn, S., 1990. Transfer Zones in the East African Rift System and Their Relevance to Hydrocarbon Exploration in Rifts. Am. Assoc. Pet. Geol. Bull. 74, 1234-1253.

Muraoka, H., Kamata, H., 1983. Displacement distribution along minor fault traces. J. Struct. Geol. 5, 483-495. doi:10.1016/0191-8141(83)90054-8

Nyblade, A., Brazier, R.A., 2002. Precambrian lithospheric controls on the development of the East African rift system. Geology 30, 755-758. doi:10.1130/0091-7613(2002)030<0755

Omosanya, K.O., Alves, T.M., 2014. Mass-transport deposits controlling fault propagation, reactivation and structural decoupling on continental margins (Espírito Santo Basin, SE Brazil). Tectonophysics 628, 158-171. doi:http://dx.doi.org/10.1016/j.tecto.2014.04.045

Osagiede, E.E., Duffy, O.B., Jackson, C.A.L., Wrona, T., 2014. Quantifying the growth history of seismically imaged normal faults. J. Struct. Geol. 66, 382-399. doi:10.1016/j.jsg.2014.05.021

Paton, D., 2006. Influence of crustal heterogeneity on normal fault dimensions and evolution: southern South Africa extensional system. J. Struct. Geol. 28, 868-886. doi:10.1016/j.jsg.2006.01.006

Peacock, D., Sanderson, D.J., 1991. Displacements, segment linkage and relay ramps in normal fault zones. J. Struct. Geol. 13, 721-733. doi:10.1016/0191-8141(91)90033-F

Pochat, S., Castelltort, S., Choblet, G., Van Den Driessche, J., 2009. High-resolution record of tectonic and sedimentary processes in growth strata. Mar. Pet. Geol. 26, 1350-1364. doi:10.1016/j.marpetgeo.2009.06.001

Pochat, S., Castelltort, S., Van Den Driessche, J., Besnard, K., Gumiaux, C., 2004. A simple method of determining sand/shale ratios from seismic analysis of growth faults: An example from upper Oligocene to lower Miocene Niger Delta deposits. Am. Assoc. Pet. Geol. Bull. 
88, 1357-1367. doi:10.1306/04290403117

Reeve, M.T., Bell, R., Duffy, O.B., Jackson, C.A.L., Sansom, E., 2015. The growth of noncolinear normal fault systems; What can we learn from 3D seismic reflection data? J. Struct. Geol. 70, 141-155. doi:10.1016/j.jsg.2014.11.007

Roberts, E., Stevens, N., O’Connor, P., Dirks, P., Gottfried, M., Clyde, W., Armstrong, R., Kemp, A., Hemming, S., 2012. Initiation of the western branch of the East African Rift coeval with the eastern branch. Nat. Geosci. 5, 289-294. doi:10.1038/ngeo1432

Rosendahl, B., 1987. Architecture of continental rifts with special reference to East Africa. Annu. Rev. Earth Planet. Sci. 15, 445-503.

Rosendahl, B., 1986. Structural Configurations of Continental Rifts. Eos, Trans. Am. Geophys. Union 67, 1208.

Saria, E., Calais, E., Stamps, D.S., Delvaux, D., Hartnady, C.J.H., 2014. Present-day kinematics of the East African Rift. J. Geophys. Res. Solid Earth 119, 3584-3600. doi:10.1002/2013JB010901

Schlische, R., 1995. Geometry and origin of fault-related folds in extensional settings. Am. Assoc. Pet. Geol. Bull. 11, 1661-1678.

Scholz, C., 1995. Deltas of the Lake Malawi Rift, East Africa: seismic expression and exploration implications. Am. Assoc. Pet. Geol. Bull. 11, 1679-1697.

Scholz, C., Cohen, A., Johnson, T.C., King, J., Moran, K., 2006. The 2005 Lake Malawi Scientific Drilling Project. Sci. Drill. 2005-2007. doi:10.2204/iodp.sd.2.04.2006

Scholz, C., Cohen, A., Johnson, T.C., King, J., Talbot, M.R., Brown, E.T., 2011a. Scientific drilling in the Great Rift Valley: The 2005 Lake Malawi Scientific Drilling Project — An overview of the past 145,000years of climate variability in Southern Hemisphere East Africa. Palaeogeogr. Palaeoclimatol. Palaeoecol. 303, 3-19. doi:10.1016/j.palaeo.2010.10.030

Scholz, C., Contreras, J., 1998. Mechanics of continental rift architecture. Geology 26, 967-970. doi:10.1130/0091-7613(1998)026<0967

Scholz, C., Johnson, T.C., Cohen, A., King, J., Peck, J.A., Overpeck, J.T., Talbot, M.R., Brown, E.T., Kalindekafe, L., Amoako, P.Y.O., Lyons, R., Shanahan, T.M., Castañeda, I.S., Heil, C.W., Forman, S.L., McHargue, L.R., Beuning, K.R.M., Gomez, J., Pierson, J., 2007. East African megadroughts between 135 and 75 thousand years ago and bearing on early-modern human origins. Proc. Natl. Acad. Sci. 104, 16416-21. doi:10.1073/pnas.0703874104

Scholz, C., Rosendahl, B., 1988. Low lake stands in Lakes Malawi and Tanganyika, East Africa, delineated with multifold seismic data. Science 240, 1645-8.

doi:10.1126/science.240.4859.1645

Scholz, C., Rosendahl, B., Versfelt, J., 1989. Seismic atlas of Lake Malawi (Nyasa). East Africa PROBE Proj. 116. 
Scholz, C., Talbot, M.R., Brown, E.T., Lyons, R., 2011b. Lithostratigraphy, physical properties and organic matter variability in Lake Malawi Drillcore sediments over the past 145,000 years. Palaeogeogr. Palaeoclimatol. Palaeoecol. 303, 38-50.

doi:10.1016/j.palaeo.2010.10.028

Shanmugam, G., 1988. Origin, Recognition, and Importance of Erosional Unconformities in Sedimentary Basins, in: Kleinspehn, K., Paola, C. (Eds.), New Perspectives in Basin Analysis SE - 5, Frontiers in Sedimentary Geology. Springer New York, pp. 83-108. doi:10.1007/978-1-4612-3788-4_5

Soreghan, M., Scholz, C., Wells, J., 1999. Coarse-grained, deep-water sedimentation along a border fault margin of Lake Malawi, Africa; seismic stratigraphic analysis. J. Sediment. Res. 69, 832-846. doi:10.2110/jsr.69.832

Specht, T.D., Rosendahl, B., 1989. Architecture of the Lake Malawi Rift, East Africa. J. African Earth Sci. 8, 355-382.

Taylor, S.K., Nicol, A., Walsh, J., 2008. Displacement loss on growth faults due to sediment compaction. J. Struct. Geol. 30, 394-405. doi:10.1016/j.jsg.2007.11.006

Tearpock, D.J., Bischke, R.E., 2002. Applied subsurface geological mapping with structural methods, 2nd ed. Prentice-Hall, TPR, Upper Saddle River, NJ.

Thornton, S.E., 1984. Basin model for hemipelagic sedimentation in a tectonically active continental margin: Santa Barbara Basin, California Continental Borderland. Geol. Soc. London, Spec. Publ. doi:10.1144/GSL.SP.1984.015.01.25

Tiercelin, J., Lezzar, K., 2002. A 300 million years history of rift lakes in Central and East Africa: an updated broad review, in: The East African Great Lakes: Limnology, Palaeolimnology and Biodiversity. pp. 3-60.

Trudgill, B., Cartwright, J., 1994. Relay-ramp forms and normal-fault linkages, Canyonlands National Park, Utah. Geol. Soc. Am. Bull. 106, 1143-1157.

Verschuren, D., 1999. Sedimentation controls on the preservation and time resolution of climateproxy records from shallow fluctuating lakes. Quat. Sci. Rev. 18, 821-837. doi:10.1016/S0277-3791(98)00065-1

Walsh, J., Nicol, A., Childs, C., 2002. An alternative model for the growth of faults. J. Struct. Geol. 24, 1669-1675. doi:10.1016/S0191-8141(01)00165-1

Walsh, J., Watterson, J., 1991. Geometric and kinematic coherence and scale effects in normal fault systems. Geol. Soc. London, Spec. Publ. 56, 193-203.

doi:10.1144/GSL.SP.1991.056.01.13

Wells, J., Scholz, C., Soreghan, M., 1999. Processes of sedimentation on a lacustrine border-fault margin; interpretation of cores from Lake Malawi, East Africa. J. Sediment. Res. 69, 816831. doi:10.2110/jsr.69.816

Wheeler, W., Karson, J., 1989. Structure and kinematics of the Livingstone Mountains border 
fault zone, Nyasa (Malawi) Rift, southwestern Tanzania. J. African Earth Sci. (and Middle East) 8, 393-413.

Whipp, P.S., Jackson, C.A.L., Gawthorpe, R., Dreyer, T., Quinn, D., 2014. Normal fault array evolution above a reactivated rift fabric; a subsurface example from the northern Horda Platform, Norwegian North Sea. Basin Res. 26, 523-549. doi:10.1111/bre.12050

Withjack, M., Schlische, R., Olsen, P., 2002. Rift-basin structure and its influence on sedimentary systems. SEPM Spec. Publ. 73, 57-81. 


\section{Figure Captions}

Figure 1: Schematic illustration of a half-graben basin with the border fault, its hangingwall block and the flexural margin shown. The types of hangingwall faults discussed in this study, fault arrays and intrabasin faults, are shown in the inset.

Figure 2: (a) The major components of the East African Rift System. RS - Red Sea, GA - Gulf of Aden, AD - Afar Depression, ATJ - Afar Triple Junction, MER - Main Ethiopian Rift, EB Eastern Branch, WB - Western Branch, OR - Okavango Rift. 1 - Lake Turkana, 2 - Lake Victoria, 3 - Lake Albert, 4 - Lake Edward, 5 - Lake Kivu, 6 - Lake Tanganyika, 7 - Lake Rukwa, 8 - Lake Malawi. (b) Lake Malawi fills most of the Malawi Rift. The bathymetry is modified from Lyons et al (2011). In the north and south basins, the lake deepens toward the eastern shoreline whereas in the central basin the lake deepens toward the western shoreline. The surface rupture from the 2009 Karonga earthquake sequence, after Macheyeki et al. (2015), in the north basin is shown. Earthquakes that occurred between 2011-09-25 and 2009-11-05 are shown. Earthquake locations and magnitudes are from the USGS Earthquake Archive. (c) Major structures in the central basin of Lake Malawi. Contours of the water bottom horizon are interpreted from a high-resolution 2D reflection seismic grid. The maximum water depth in the central basin is $\sim 700 \mathrm{~m}$. The central basin border fault system consists of three segments. Interpretation for the north and central segments is from the high-resolution seismic data. Interpretation for the south segment is from the PROBE data only. A relay ramp between the northern and southern segments of the border fault system carries sediments from the South Rukuru River into the deepest part of the lake. The Lipchili Fault Zone is a structural high separating the deepest part of Lake Malawi from the study area. The study area is shown in detail in Figure 3. 
Figure 3 (a): Detailed fault map for the study area, showing high-resolution fault interpretation and locations for syndepositional fault analysis (black circles with grey fill). The Lipichili Fault Zone (LFZ) has two sections, a northeast-southwest oriented section and a north-south oriented section. The drillsite (black circle with white fill) intersects one of the north-south lines in the seismic grid (see Figure 4a). The 600m lowstand contour from Lyons et al (2011) is included. (b): Line drawing based on PROBE line 86-828, published in Specht and Rosendahl (1989) and the Project PROBE Atlas (Scholz et al., 1989). The hangingwall of the border fault is broken up by the LFZ. This profile shows the full sedimentary sequence in the central basin with the approximate base of this study indicated. Here, acoustic basement is assumed to be equivalent to crystalline basement in the east, but this choice is less certain in the west.

Figure 4: High-resolution seismic profiles through the study area. T-z analysis locations are indicated by the number corresponding to their location on Figure 3. The colored horizons define the bases of the same-colored units in Figure 5. A'-A: North-south profile through the drillsite showing horizons used to define chronostratigraphic sequences. Water depth at the drillsite is $\sim 590 \mathrm{~m}$. The drillsite is not in the hangingwall of any major faults. B-B': East-west profile through the south end of the study area. The LFZ and fault IB-E02 are much further apart than to the north (Figure 3b). C-C': East-west profile through the north end of the LFZ. In the LFZ, decrease in resolution with depth is apparent. D-D': East-west profile through the center of the study area showing the LFZ and fault IB-E01. There is apparent fault drag on fault IB-E02.

Figure 5: Data used to correlate seismic horizons (in time) with the age model from Lyons et al (Lyons et al., 2015). Whole-core density log from the drilling project and interval velocities from an unpublished multichannel 2D seismic reflection line crossing the drillsite were used to create a synthetic seismogram. The velocity curve and synthetic seismogram are the final ones 
developed after tying the synthetic to the seismic line in Figure 4. The horizon times were converted to depths using the final velocity curve to calculate the ages.

Figure 6: Three seismic profiles intersecting the same fault at approximately the same location but different orientations. (a) The small angle between the seismic line and the fault results in the fault being imaged as two vertical segments, whereas in (b) and (c) the fault appears continuous along-dip. (d) Location map (location 2 in Figure 3) showing the angles between the seismic lines in the fault in (a) to (c). (e) Stratigraphic throw vs. depth (in time) for the fault on each seismic line. The T-z profiles for the seismic lines shown in $\mathrm{b}$ and $\mathrm{c}$ overlap. A profile in the true dip direction at this location is expected to have T-z values in the same range.

Figure 7 (a): Schematic illustration of horizon cutoffs used for syndepositional fault analysis. The vertical separation, or stratigraphic throw, is the difference between the hangingwall and footwall cutoff times for a give horizon. In the hangingwall block of the schematic fault, we show the difference between vertical thickness used for isochore maps and the stratigraphic thickness used for isopach and isochron maps. (b) A schematic stratigraphic throw (T) vs depth (z) plot with examples of positive, negative, and null slopes. The interpretation of these slopes is discussed in the text. (c): Schematic illustration, after Cartwright et al (1995) of stratigraphic throw $(\mathrm{T})$ vs along-strike distance (x) for faults that grow by radial propagation. In this schematic, profile (i) is the oldest profile and (iii) is the youngest. As the fault grows through tip propagation, throw increases (d): Schematic illustration, after Cartwright et al (1995) of a T-x plot for faults that grow by segment linkage where (i) is the oldest profile and (iii) is the youngest. Displacement is initially small when the segments are not linked, but increases as segments link and total fault length grows. 
Figure 8: Stratal accumulation rates (SAR) calculated in the study area. Hangingwall SARs and footwall SARs were calculated for each of the numbered points in Figure 3. The mean hangingwall (black) and footwall (grey and white) SARs were calculated for each sequence, and are shown as thick bars with rectangles extending one standard deviation above and below the mean. The purple line is the drillsite SAR for each sequence. The lake level curve is modified from Lyons et al (Lyons et al., 2015). Red intervals are periods when the lake level was $>400 \mathrm{~m}$ below modern level, orange intervals are periods when the lake level was 200-400 m below modern level, and blue intervals are times when lake level was within $200 \mathrm{~m}$ of modern level.

Figure 9: Isochore map (in TWTT) of sequence 1 (1176-1308 ka) showing the development of a thick zone along the entire length of the LFZ, interpreted as a syncline depocenter. The midrange isochore value for this sequence is $70 \mathrm{~ms}$. All regions where the isochore is thicker than 70 ms are shaded grey.

Figure 10: Stratigraphic throw-depth (T-z) profiles for the intrabasin faults (labeled on the inset map). The profile location is given by the number at the base of each profile, which corresponds to the locations on the inset map and Figure 3. (a) Fault IB-E01. (b) Fault IB-E02.

Figure 11: (a) T-z profiles for all data points in the Lipichili Fault Zone (LFZ). Numbers at the base of each profile correspond to location numbers on the inset map and in Figure 3. (b) T-x profiles for laterally-averaged points in the LFZ. Lower case letters at the base of the profile indicate the along-strike position corresponding to the inset map, which shows only the data points for the LFZ. At each along-strike position, the throws and depths for each location were averaged. For example, at location a, data from three faults was combined and at location $\mathrm{h}$ data from five faults was combined. 


\section{Tables}

Table 1: Ages of major sequences in the Malawi Rift

\begin{tabular}{|l|r|r|}
\hline Sequence & $\begin{array}{r}\text { Contreras et al (2000) } \\
\text { sequence duration }\end{array}$ & $\begin{array}{r}\text { New sequence duration using } \\
\text { drillsite age model }\end{array}$ \\
\hline Songwe & $0-1.6 \mathrm{Ma}$ & $0-\sim 249 \mathrm{ka}$ \\
\hline Mbamba & $1.6 \mathrm{Ma}-\sim 2.3 \mathrm{Ma}$ & $\sim 249 \mathrm{ka}-\sim 1.1 \mathrm{Ma}$ \\
\hline Baobab & $\sim 2.3 \mathrm{Ma}-\sim 6.33 \mathrm{Ma}$ & $\sim 1.1 \mathrm{Ma}-\sim 3.4 \mathrm{Ma}$ \\
\hline Nyasa & $\sim 6.33 \mathrm{Ma}-\sim 8.6 \mathrm{Ma}$ & $\sim 3.4 \mathrm{Ma}-\sim 4.6 \mathrm{Ma}$ \\
\hline
\end{tabular}


Table 2: Lake Malawi Data Acquisition Parameters (modified from Scholz et al., 2011; Lyons et al., 2011)

\begin{tabular}{|c|c|c|c|c|c|c|c|c|c|c|}
\hline Data & $\begin{array}{l}\text { Total } \\
\text { length } \\
(\mathrm{km})\end{array}$ & $\begin{array}{l}\text { Line } \\
\text { spacing } \\
(\mathrm{km})\end{array}$ & Source & $\begin{array}{l}\text { Bandwidth } \\
\quad(\mathrm{Hz})\end{array}$ & Receiver & $\begin{array}{l}\text { Acquisition } \\
\text { system }\end{array}$ & $\begin{array}{l}\text { Record } \\
\text { length } \\
(s)\end{array}$ & $\begin{array}{l}\text { Sample } \\
\text { Rate } \\
(\mathrm{ms})\end{array}$ & $\begin{array}{l}\text { Processing } \\
\text { Parameters }\end{array}$ & Positioning \\
\hline $\begin{array}{l}\text { Project } \\
\text { PROBE } \\
\text { 24-fold multi- } \\
\text { channel } \\
\text { seismic } \\
(1986-1987)\end{array}$ & $>3500$ & $\sim 25-50$ & $\begin{array}{l}40-140 \text { in }^{3} \\
\text { single } \\
\text { airguns or } \\
\text { multigun } \\
\text { arrays }\end{array}$ & $8-128$ & $\begin{array}{l}\text { 960m long, } 48 \\
\text { channel GECO } \\
\text { cable, } 1 \mathrm{~m} \\
\text { phone spacing, } \\
\text { 20m group } \\
\text { interval, } 440 \mathrm{~m} \\
\text { lead-in }\end{array}$ & $\begin{array}{l}\text { Texas } \\
\text { Instruments } \\
\text { DPS V }\end{array}$ & 6 & 2 & $\begin{array}{l}\text { Demultiplexing, F- } \\
\text { K filtering, } \\
\text { deconvolution, } \\
\text { velocity analysis, } \\
\text { normal moveout, } \\
\text { CDP stacking, } \\
\text { bandpass filter } \\
(8 / 10-40 / 55 \mathrm{~Hz})\end{array}$ & $\begin{array}{l}\text { TRANSAT } \\
\text { satellites and } \\
\text { radar; GPS } \\
\text { used } 20 \% \text { of } \\
\text { acquisition } \\
\text { time }\end{array}$ \\
\hline $\begin{array}{l}\text { High- } \\
\text { resolution } \\
\text { single-channel } \\
\text { seismic } \\
(1995)\end{array}$ & $>2000$ & 2 & $\begin{array}{l}12 \mathrm{in}^{3} \text { Bolt } \\
600 \mathrm{~B} \text { airgun } \\
-2000 \mathrm{psi}\end{array}$ & $80-700$ & $\begin{array}{l}\text { ITI 10-phone } \\
\text { solid towed } \\
\text { array }\end{array}$ & Elics-Delph 2 & 2 & 0.5 & $\begin{array}{l}\text { Promax software - } \\
\text { 3-trace horizontal } \\
\text { stack, bandpass } \\
\text { filter }(80-500 \mathrm{~Hz}) \text {, } \\
\text { 100ms AGC, trace } \\
\text { balancing }\end{array}$ & $\begin{array}{l}\text { Autonomous } \\
\text { GPS - } \\
\text { acquired } \\
\text { every } \sim 5 \mathrm{~s}\end{array}$ \\
\hline $\begin{array}{l}\text { High- } \\
\text { resolution } \\
\text { single-channel } \\
\text { seismic } \\
(2000)\end{array}$ & 1840 & 2 & $\begin{array}{l}10 \mathrm{in}^{3} \text { and } \\
20 \mathrm{in}^{3} \text { Bolt } \\
600 \mathrm{~B} \text { airgun } \\
-2000 \text { psi }\end{array}$ & $50-540$ & $\begin{array}{l}\text { S.I.G. } 10 \mathrm{~m} 16 \\
\text { hydrophone } \\
\text { element } \\
\text { streamer }\end{array}$ & Elics-Delph 2 & 3 & 0.5 & $\begin{array}{l}\text { Promax software - } \\
\text { 3-trace horizontal } \\
\text { stack, band-pass } \\
\text { filter }(80-500 \mathrm{~Hz}) \text {, } \\
100 \mathrm{~ms} \text { AGC, trace } \\
\text { balancing }\end{array}$ & $\begin{array}{l}\text { Continuous } \\
\text { Autonomous } \\
\text { GPS }\end{array}$ \\
\hline Data & \multicolumn{2}{|c|}{ Water Depth $(m)$} & \multicolumn{2}{|c|}{ Total Drilled Depth $(\mathrm{m})$} & $\begin{array}{l}\text { Downhole } \\
\text { Logging }\end{array}$ & \multicolumn{3}{|c|}{ Shore-based whole-core logging } & \multicolumn{2}{|c|}{$\begin{array}{l}\text { High-resolution whole-core } \\
\text { logging (US) }\end{array}$} \\
\hline $\begin{array}{l}2005 \text { Lake } \\
\text { Malawi } \\
\text { Scientific } \\
\text { Drilling } \\
\text { Project - Site } 1 \\
\end{array}$ & \multicolumn{2}{|l|}{592} & \multicolumn{2}{|l|}{380.7} & Gamma & \multicolumn{3}{|c|}{$\begin{array}{l}\text { GEOTEK instrument: GRAPE } \\
\text { density, magnetic susceptibility, P- } \\
\text { wave velocity }\end{array}$} & \multicolumn{2}{|c|}{$\begin{array}{l}\text { GRAPE density, magnetic } \\
\text { susceptibility, P-wave velocity, } \\
\text { natural gamma ray }\end{array}$} \\
\hline
\end{tabular}


Table 3: Lake cycles per sequence, based on estimated lake level cyclicity in Lyons et al (2015)

\begin{tabular}{|l|r|r|r|r|r|r|r|r|r|}
\hline Sequence & 01 & 02 & 03 & 04 & 05 & 06 & 07 & 08 & 09 \\
\hline Lake cycles/sequence & 13.1 & 23.3 & 18.4 & 10.45 & 8.95 & 5.6 & 5 & 3.05 & 2.1 \\
\hline
\end{tabular}




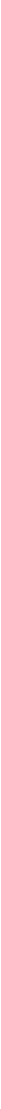






2

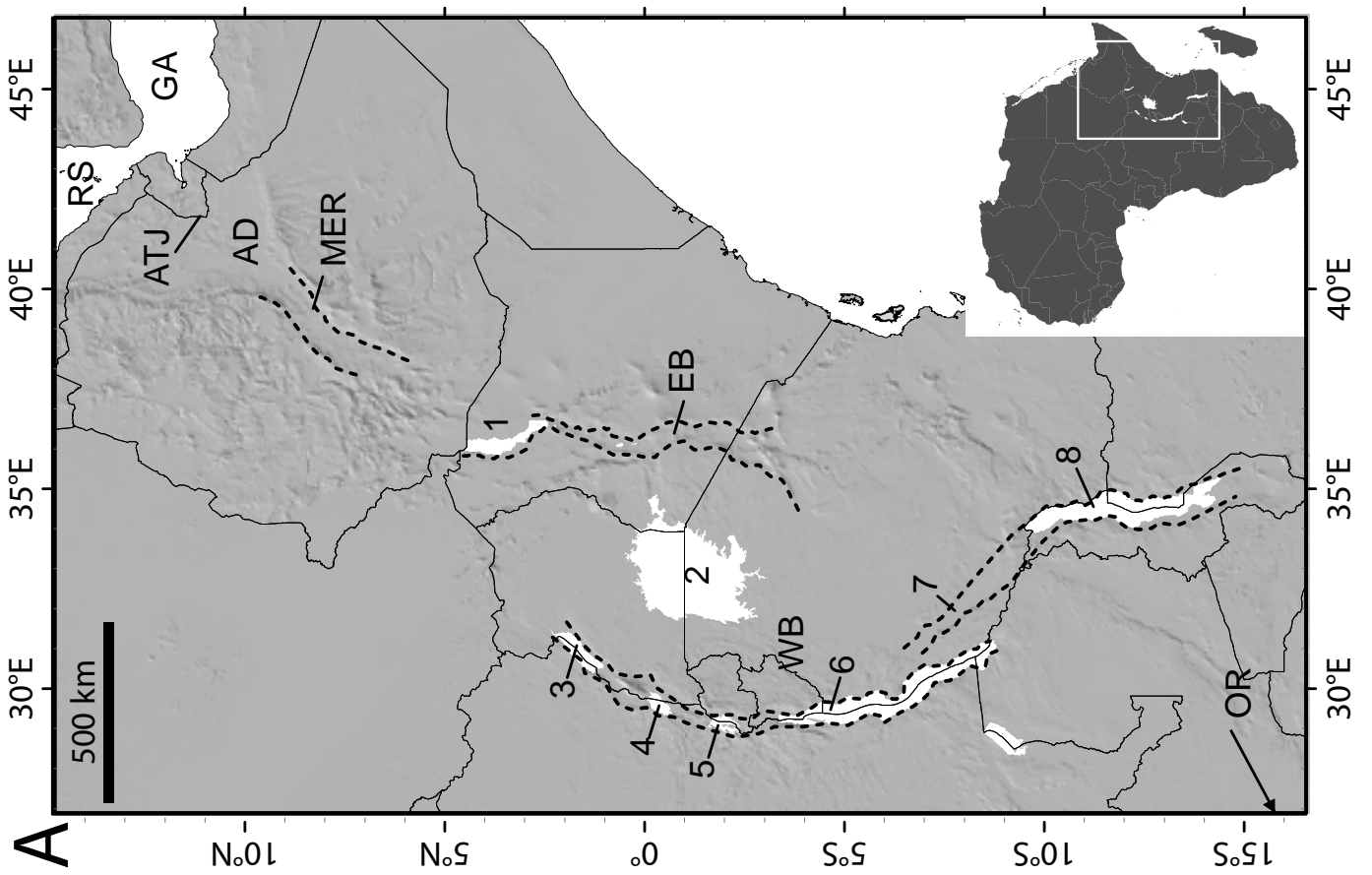



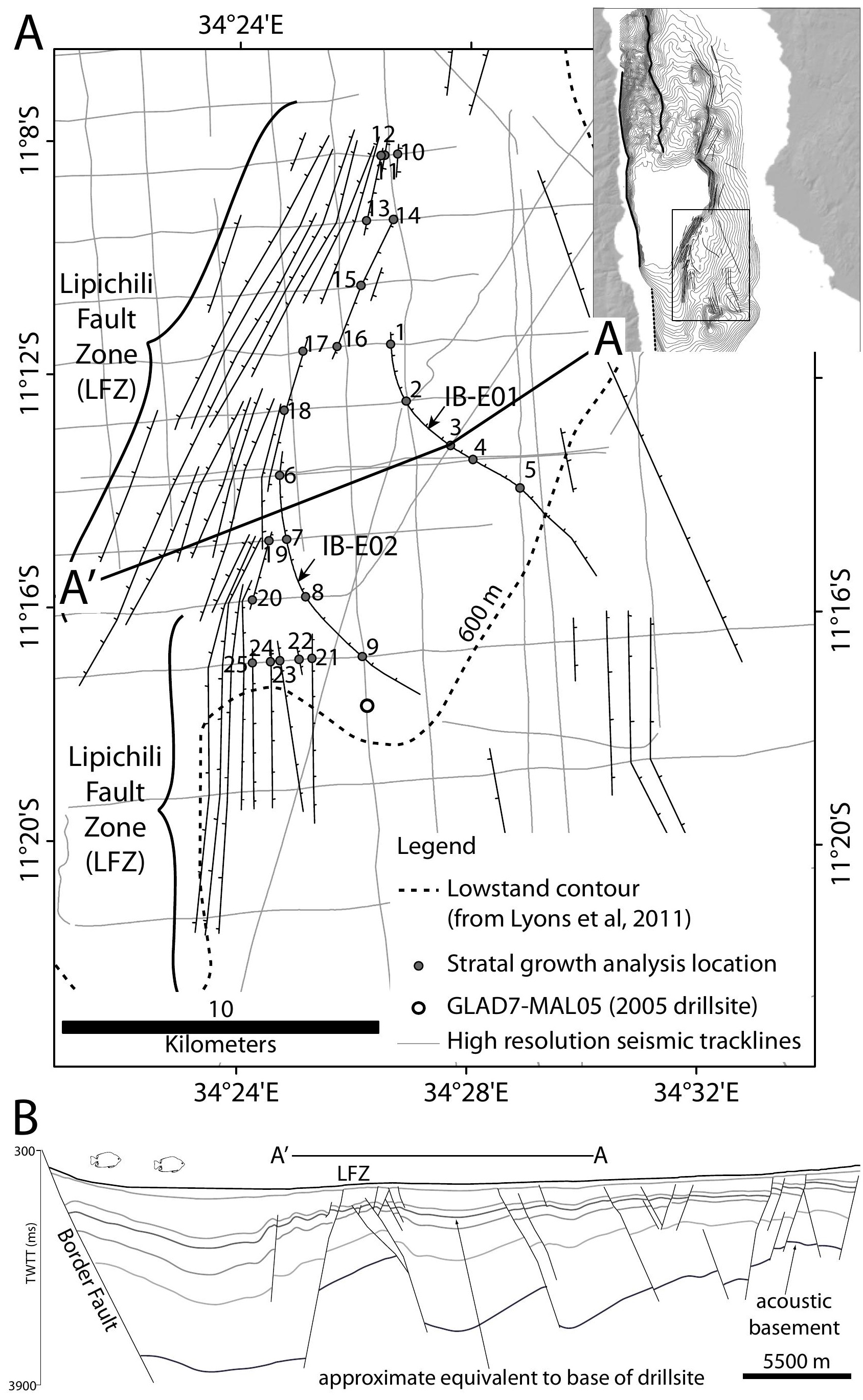


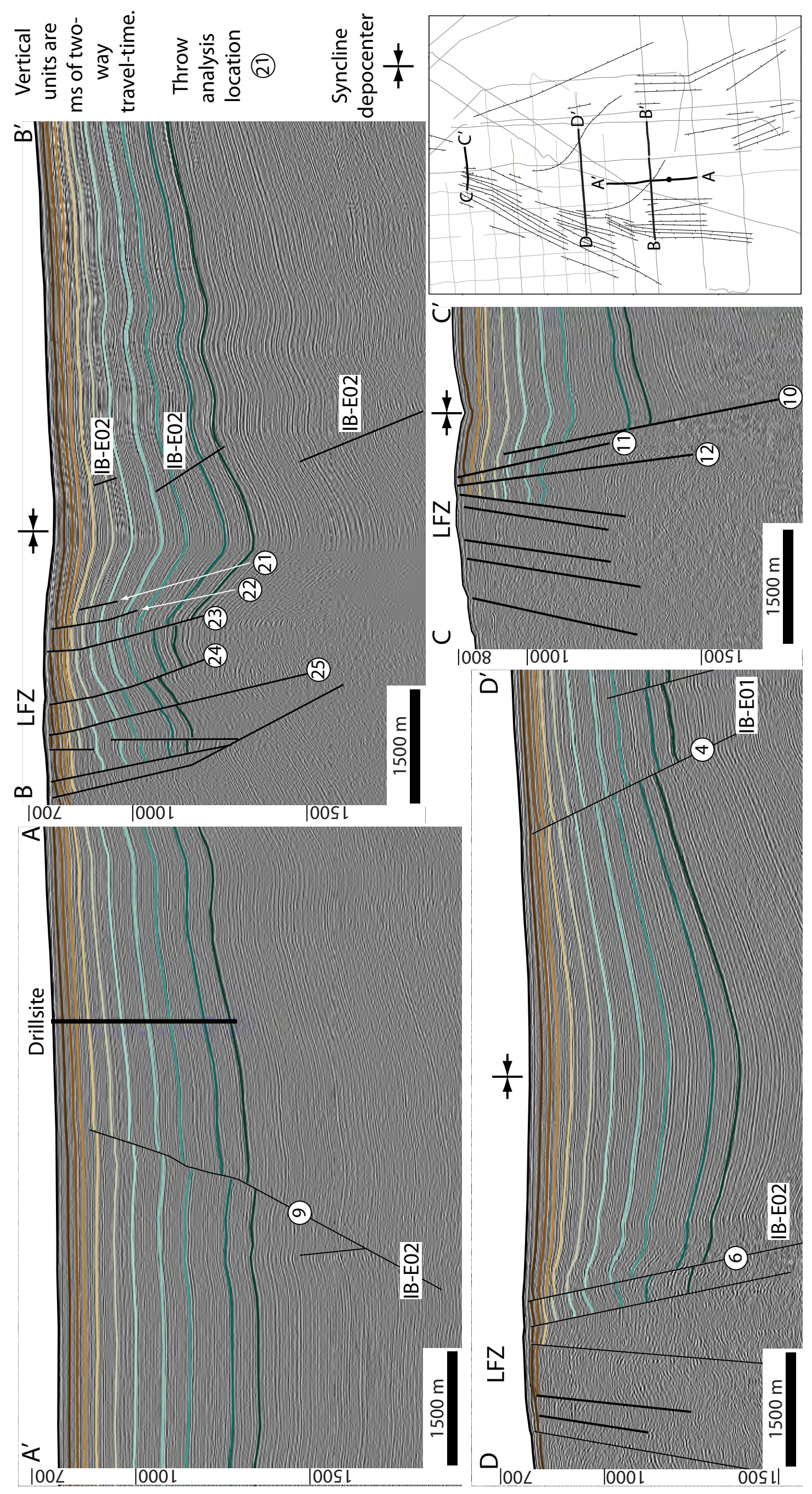




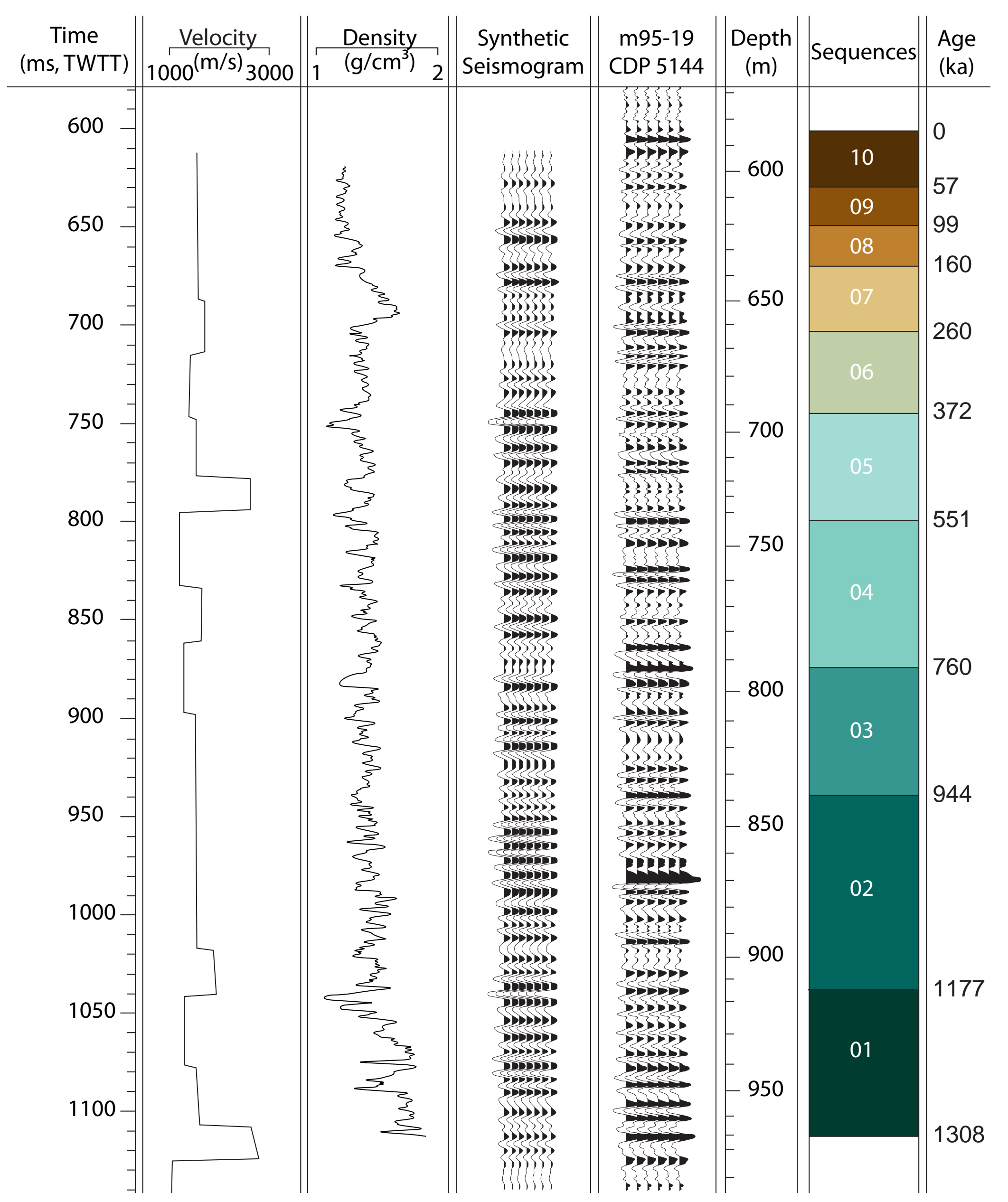



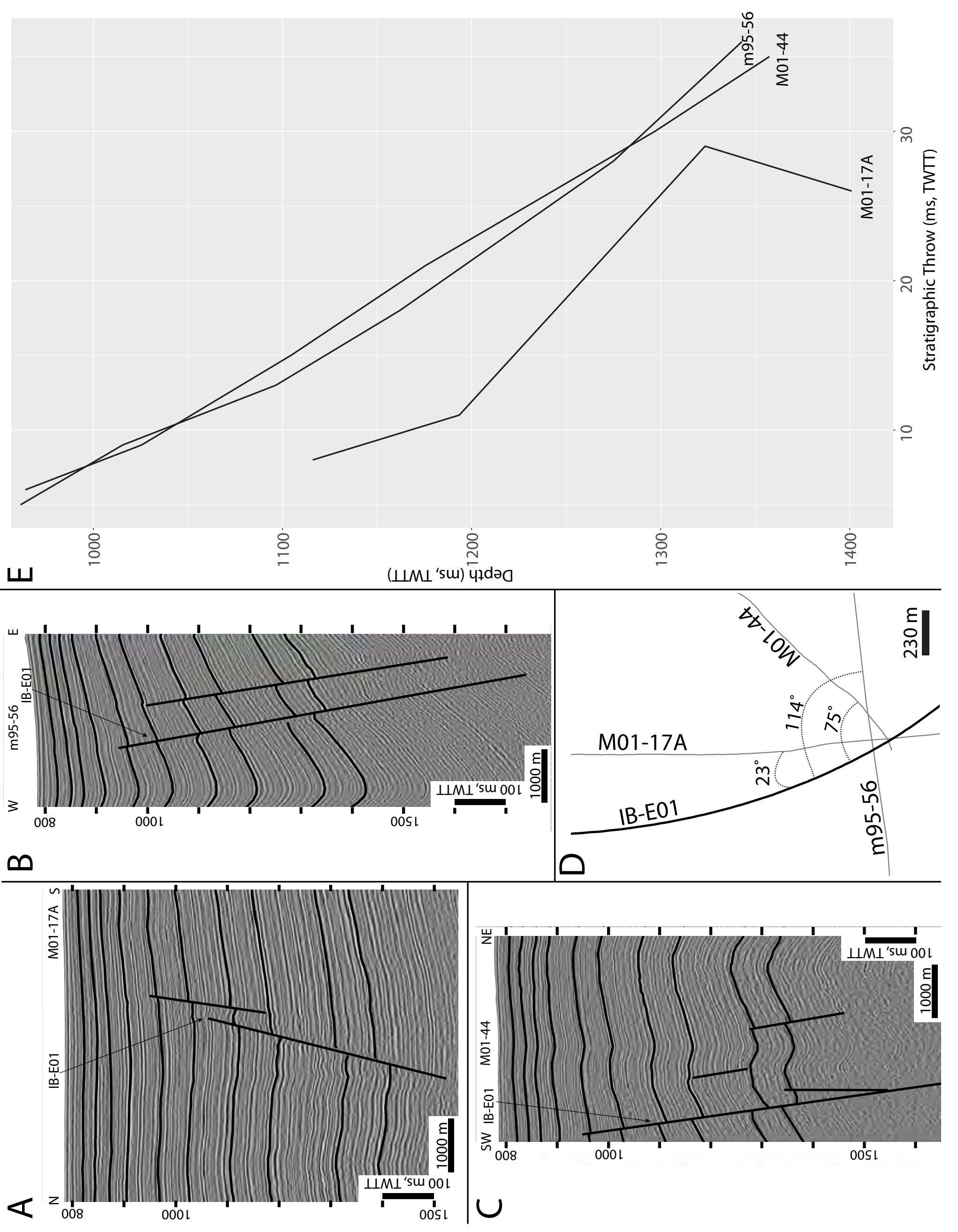


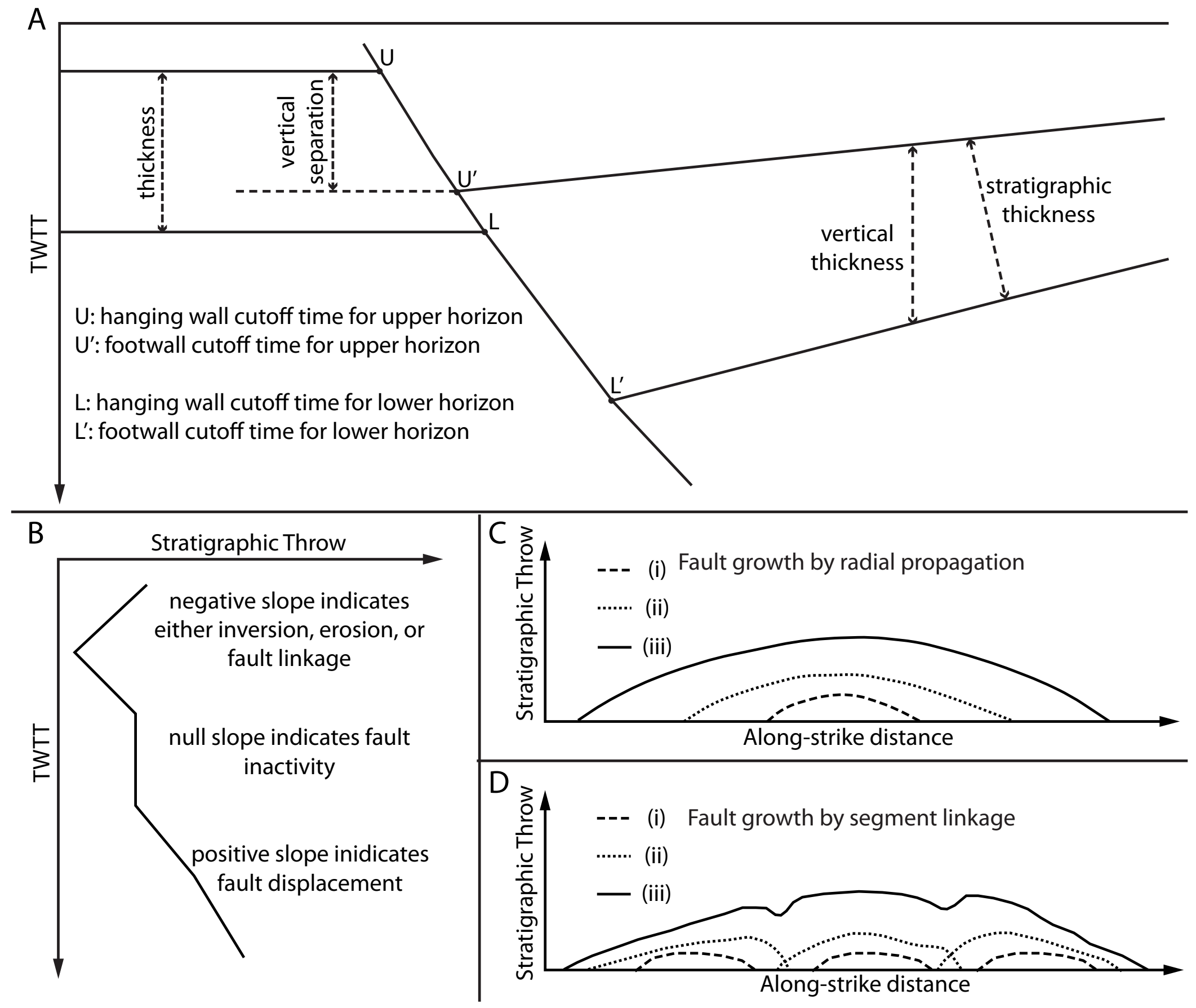



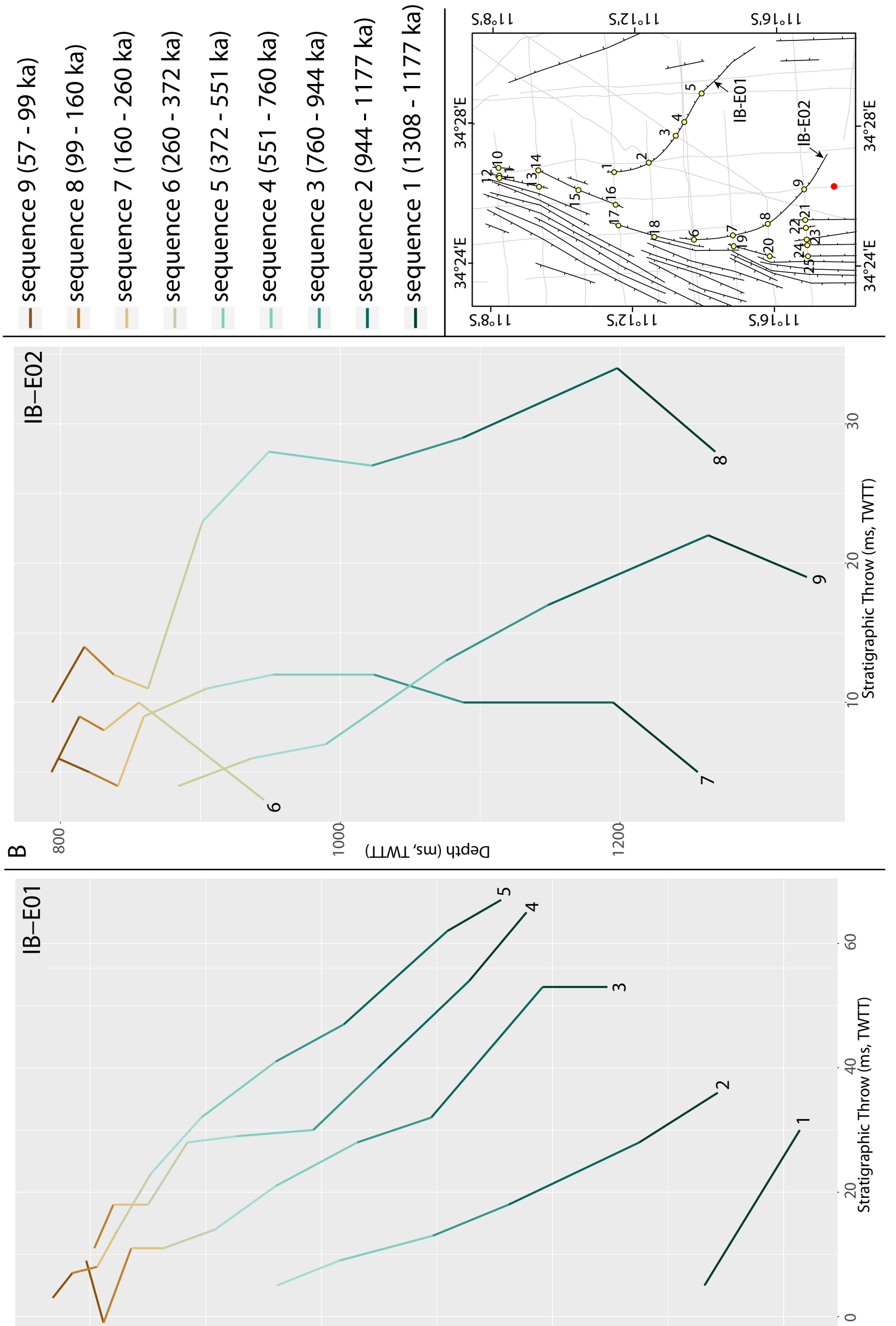

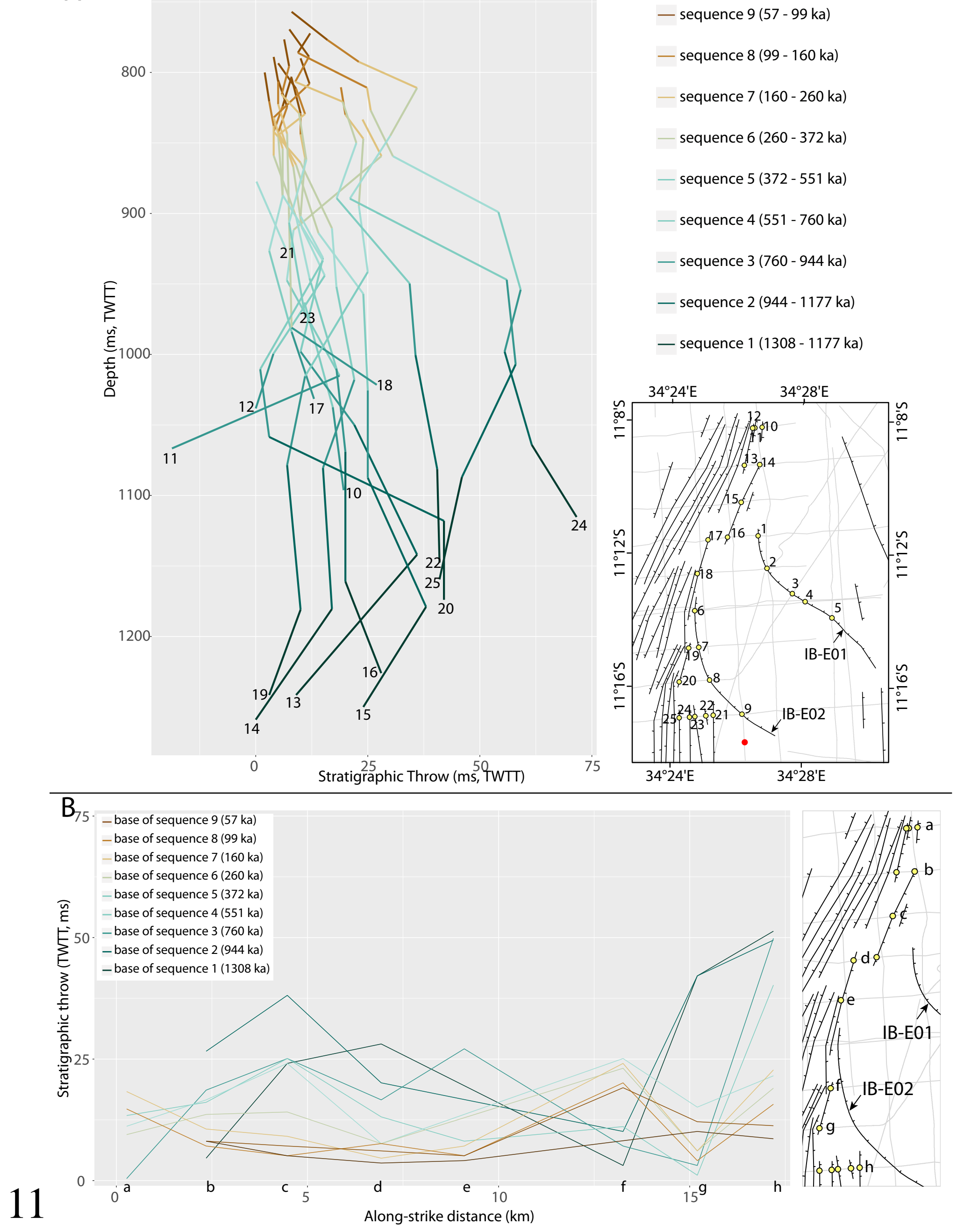